\title{
Trends in Utility Green Pricing Programs (2005)
}

Technical Report NREL/TP-640-40777

October 2006

Lori Bird and Elizabeth Brown

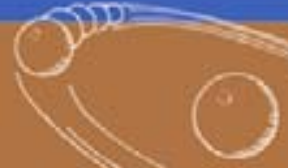




\section{Trends in Utility Green Pricing Programs (2005)}

\section{Lori Bird and Elizabeth Brown}

Prepared under Task No. ASG6.1003

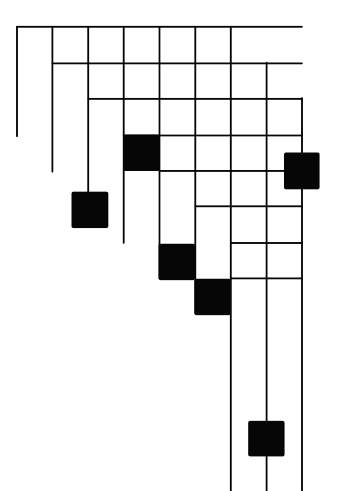

National Renewable Energy Laboratory

1617 Cole Boulevard, Golden, Colorado 80401-3393

303-275-3000 • www.nrel.gov

Operated for the U.S. Department of Energy

Office of Energy Efficiency and Renewable Energy

by Midwest Research Institute • Battelle

Contract No. DE-AC36-99-G010337 


\section{NOTICE}

This report was prepared as an account of work sponsored by an agency of the United States government. Neither the United States government nor any agency thereof, nor any of their employees, makes any warranty, express or implied, or assumes any legal liability or responsibility for the accuracy, completeness, or usefulness of any information, apparatus, product, or process disclosed, or represents that its use would not infringe privately owned rights. Reference herein to any specific commercial product, process, or service by trade name, trademark, manufacturer, or otherwise does not necessarily constitute or imply its endorsement, recommendation, or favoring by the United States government or any agency thereof. The views and opinions of authors expressed herein do not necessarily state or reflect those of the United States government or any agency thereof.

Available electronically at http://www.osti.gov/bridge

Available for a processing fee to U.S. Department of Energy and its contractors, in paper, from:

U.S. Department of Energy

Office of Scientific and Technical Information

P.O. Box 62

Oak Ridge, TN 37831-0062

phone: 865.576 .8401

fax: 865.576 .5728

email: mailto:reports@adonis.osti.gov

Available for sale to the public, in paper, from:

U.S. Department of Commerce

National Technical Information Service

5285 Port Royal Road

Springfield, VA 22161

phone: 800.553.6847

fax: 703.605.6900

email: orders@ntis.fedworld.gov

online ordering: http://www.ntis.gov/ordering.htm 


\section{Acknowledgments}

This work was funded by the U.S. Department of Energy's (DOE) Office of Energy Efficiency and Renewable Energy (EERE). The authors wish to thank Linda Silverman of EERE and the EERE renewable energy technology programs for their support of this work. The authors also wish to thank Ed Holt of Ed Holt and Associates, Dan Lieberman of the Center for Resource Solutions, and Blair Swezey of NREL for their thoughtful review of the document, as well as Michelle Kubik of NREL for her editorial support. Finally, the authors thank the many utility contacts that provided the information summarized in this report, and Lynne Fenn of NREL and Diane Zipper of the Renewable Northwest Project for their assistance in collecting data from utilities. Additional information on green power market trends and activities can be found on the U.S. DOE’s Green Power Network Web site (http://www.eere.energy.gov/greenpower/). 


\section{TABLE OF CONTENTS}

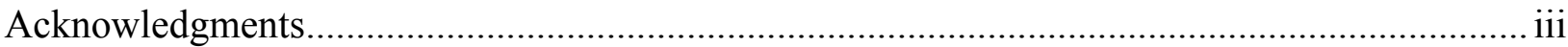

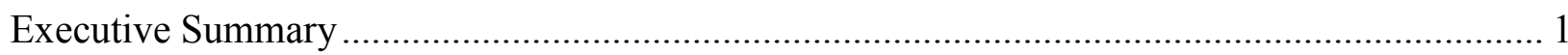

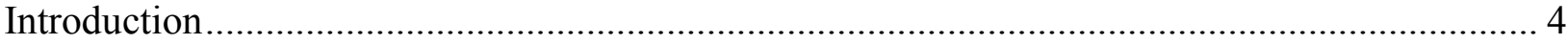

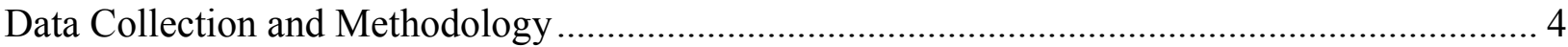

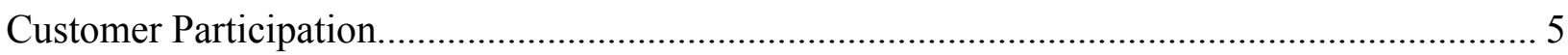

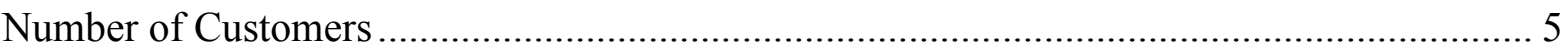

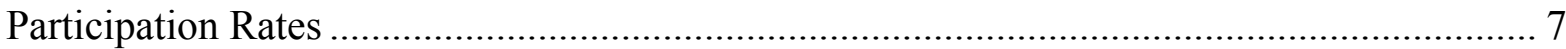

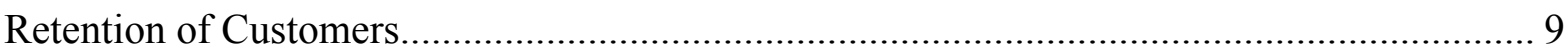

Renewable Energy Sales and Supplies ……………….................................................... 9

Green Power Sales and Revenues................................................................................. 9

Renewable Energy Resources Supplying Green Pricing Programs...................................... 11

Green Energy Sales vs. Total Utility Sales .................................................................... 12

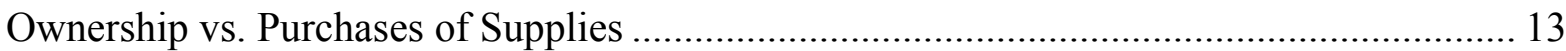

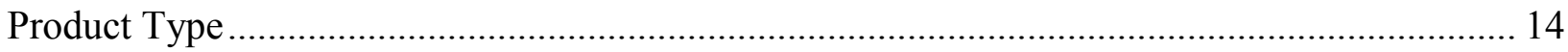

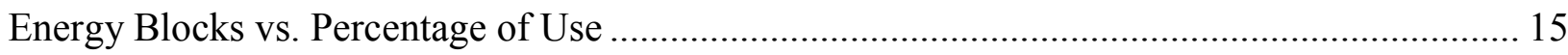

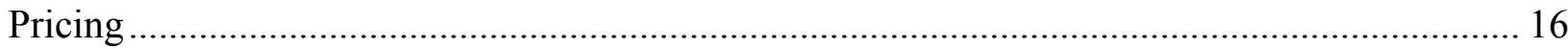

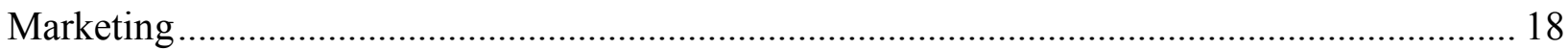

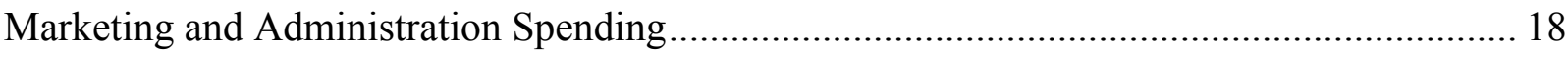

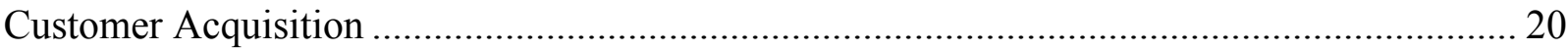

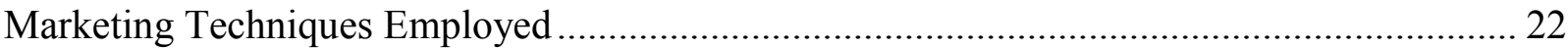

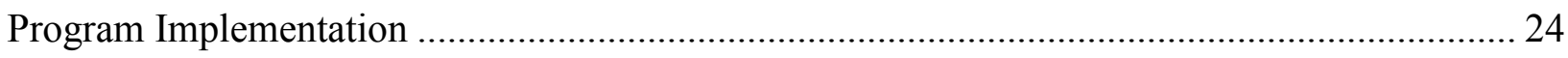

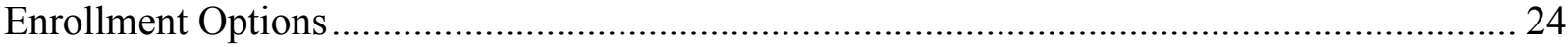

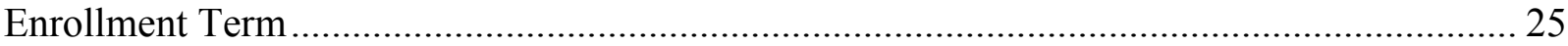

Program Evaluations and Market Research .......................................................................... 25

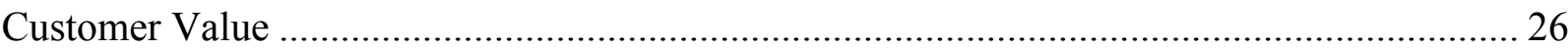

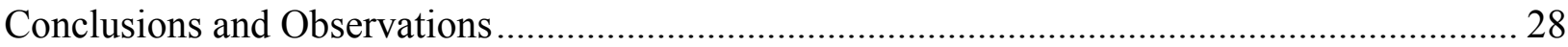

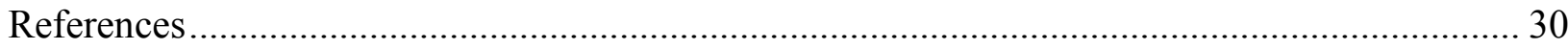

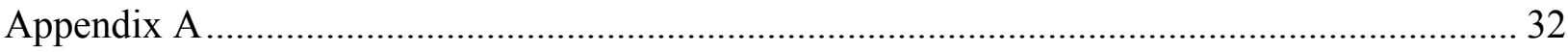

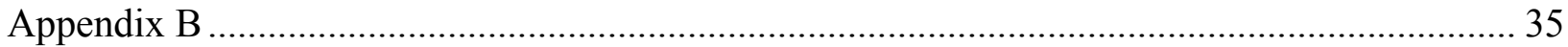

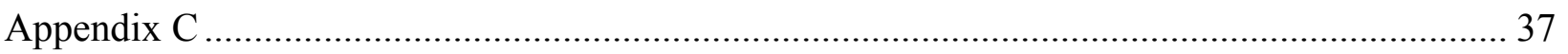




\section{LIST OF TABLES}

Table 1: Number of Participants in Utility Green Power Programs (in Regulated and Competitive Electricity Markets) ............................................................................ 5

Table 2: Estimated Cumulative Number of Customers Participating in Utility Green

Pricing Programs (Regulated Electricity Markets Only) .................................... 6

Table 3: Number of Customer Participants by Program, 2004-2005.................................... 7

Table 4: Customer Participation Rates in Utility Green Pricing Programs ............................. 7

Table 5: Customer Participation Rates in Utility Green Pricing Programs, 2004-2005 ............ 8

Table 6: $\quad$ Average Green Pricing Participation Rates by Utility Type................................... 8

Table 7: $\quad$ Median Green Pricing Participation Rates by Utility Type .................................... 8

Table 8: Fraction of Customers Dropping Out of Green Pricing Programs ............................ 9

Table 9: Sales of Renewable Energy through Utility Green Power Programs in Regulated and Competitive Electricity Markets (million kWh) ............................. 10

Table 10: Annual Sales of Green Energy through Utility Green Pricing Programs (Regulated Electricity Markets Only), millions of kWh........................................ 10

Table 11: Average Purchases of Green Energy Per Green Pricing Customer (kWh/year)........ 10

Table 12: Renewable Energy Sales through Utility Programs (million kWh).......................... 11

Table 13: Renewable Energy Sources Supplying Green Pricing Programs, 2005 .................. 11

Table 14: Estimated Cumulative Capacity Supplying Utility Green Pricing Programs,

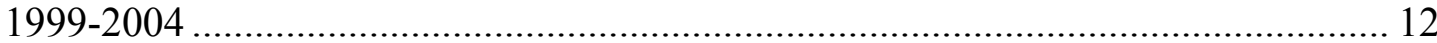

Table 15: Green Energy Sales as a Percent of Utility Electricity Sales, 2005 ........................ 12

Table 16: Average, Median, and Range Green Energy Sales as a Percent of Utility Electricity Sales......................................................................................... 13

Table 17: Residential Monthly Expenditures on Green Power and Annual Program

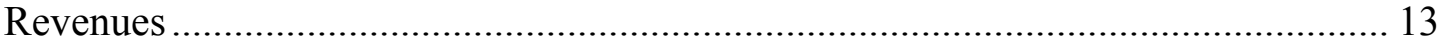

Table 18: Utility Procurement of Renewable Energy Supplies ............................................. 14

Table 19: REC Purchases by Utilities to Supply Green Pricing Programs ............................. 14

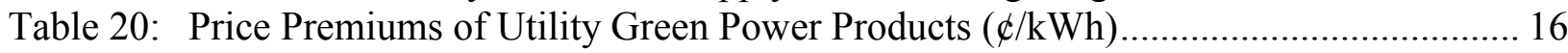

Table 21: Green Pricing Premiums by Utility Type, 2003-2005 ( $\not / \mathrm{kWh})$............................. 17

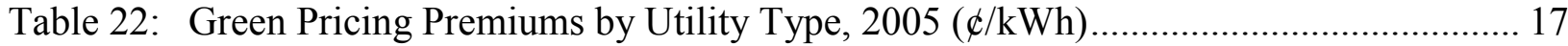

Table 23: Utility Expenditures on Marketing in 2005 (Excluding Staff Time)....................... 19

Table 24: Utility Expenditures on Program Administration in 2005 (Including Staff

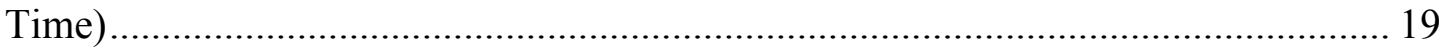

Table 25: Marketing and Administrative Expenditures as Percentage of Premium, 2005 ........ 20

Table 26: Explantion of Costs Born by Nonparticipants, 2005 .......................................... 20

Table 27: Residential Customer-Acquisition Costs by Year .............................................. 21

Table 28: Residential Customer-Acquisition Costs by Utility Size...................................... 21

Table 29: Marketing Techniques Used by Utilities ......................................................... 23

Table 30: Number of Marketing Techniques Used by Utilities ......................................... 24

Table 31: Methods of Enrolling in Green Pricing Programs ............................................... 24

Table 32: Enrollment Term by Customer Segment ......................................................... 25

Table 33: Methods of Providing Additional Program Benefits ............................................ 27

Table B-1: Utilities Offering Green Pricing Programs in Regulated Markets, 2005 .................. 35

Table B-2: Utility/Marketer Green Power Programs in Restructured Electricity Markets, 2005. 
Table C-1: Green Pricing Program Renewable Energy Sales (as of December 2005) ............... 37

Table C-2: Total Number of Customer Participants (as of December 2005) ............................ 38

Table C-3: Customer Participation Rate (as of December 2005) ........................................... 39

Table C-4: Price Premium Charged for New, Customer-Driven Renewable Power (as of December 2005)

\section{LIST OF FIGURES}

Figure 1: Utility Green Pricing Program Premiums (Energy-Based Programs Only) .............. 16

Figure 2: Customer-Acquisition Costs (2005) ..................................................................... 21 


\section{Executive Summary}

In the early 1990s, only a handful of utilities offered their customers a choice of purchasing electricity generated from renewable energy sources. Today, more than 600 utilities - or about $20 \%$ of all utilities nationally_provide their customers a "green power" option. Because some utilities offer programs in conjunction with cooperative associations or other publicly owned power entities, the number of distinct programs totals more than 130. Through these programs, more than 50 million customers have the ability to purchase renewable energy to meet some portion or all of their electricity needs - or make contributions to support the development of renewable energy resources. Typically, customers pay a premium above standard electricity rates for this service.

This report presents year-end 2005 data on utility green pricing programs, and examines trends in consumer response and program implementation over time. The data in this report, which were obtained via a questionnaire distributed to utility green pricing program managers, can be used by utilities to benchmark the success of their green power programs. It is important to note that this report covers only a portion of voluntary markets for renewable energy. It does not cover green power sold by independent marketers except for cases in which the marketers work in conjunction with utilities or default electricity suppliers. ${ }^{1}$

At the end of 2005, green pricing sales were equivalent to more than $740 \mathrm{MW}$ of new renewable energy capacity. Thus, green pricing continues to be a viable strategy for supporting the development of new renewable energy sources. While utility green power programs continue to exhibit strong growth in overall sales, current success can be attributed to a relatively small number of programs.

The following is a summary of key findings from this analysis.

\section{Consumer Response}

- Despite a year in which electricity costs increased substantially throughout the country, sales of renewable energy through utility green power programs continued to exhibit strong growth. Collectively, utilities sold nearly 3 billion kilowatt-hours $(\mathrm{kWh})$ of green power to more than 450,000 customers in 2005 . A relatively small number of programs still account for the majority of utility green power sales and customers, with the top 10 programs accounting for about $70 \%$ of sales and $65 \%$ of customers, similar to 2004 .

- In restructured electricity markets, both the number of customers and sales of renewable energy through utility/marketer programs more than doubled during 2005. This rapid growth may be attributed to the early stage of these programs as well as the fact that they are promoted by independent companies specializing in renewable energy marketing, which have a vested financial interest in their success.

- In traditionally regulated electricity markets, sales through utility green pricing programs increased 33\% following annual growth rates in excess of 40\% in 2003 and 2004. The number of customers purchasing green power increased by $20 \%$, a slower pace than sales.

\footnotetext{
${ }^{1}$ For data on the entire voluntary renewable energy market, see Bird and Swezey (2005a).
} 
- The average participation rate across all green pricing programs increased slightly to $1.5 \%$. The top 10 utility green pricing programs exhibited participation rates ranging from $5 \%$ to $14 \%$.

- The fraction of customers dropping out of green pricing programs fell to a median of 5\% in 2005 from nearly $9 \%$ in 2004, reversing a trend of increasing dropout rates in previous years.

\section{Renewable Energy Supplies}

- In 2005, about one-third of utilities owned the renewable energy generation sources used to supply a significant portion of the energy sold to their green pricing customers. The remainder purchase renewable power or renewable energy certificates (RECs) from third parties to supply their programs.

- The use of RECs continued to climb, with utilities purchasing more than 1 billion $\mathrm{kWh}$ of RECs to serve green pricing customers in 2005, nearly a 50\% increase from 2004 . RECs represented more than $40 \%$ of all green pricing sales in 2005 .

- The bulk of green pricing sales (87\%) were sourced from "new"2 renewable energy facilities. Wind energy accounted for $76 \%$ of sales, followed by biomass $(17 \%)$, hydro $(4 \%)$, geothermal $(3 \%)$, and solar $(0.2 \%)$.

- Renewable energy sales to green pricing customers represent a capacity equivalent of more than $740 \mathrm{MW}$ of new renewable energy sources.

\section{Pricing and Revenues}

- The average price premium charged for green power through green pricing programs continued to decline, falling to $2.36 \notin / \mathrm{kWh}$ in 2005 from $2.45 \notin / \mathrm{kWh}$ in 2004 . Since 2000 , the premium has declined at an annual average rate of more than $7 \%$.

- A number of utilities reduced their green pricing premiums because of higher fossil fuel costs or because they were able to enter into more favorable contracts for renewable energy supplies. Several other utilities reported that renewable energy was offered at rates less than standard electricity service because their green power customers are exempt from rate increases resulting from fossil fuel cost changes.

- Several utilities introduced lower price premiums for bulk purchases by large, nonresidential purchasers.

- In 2005, residential customers paid less than $\$ 5$ per month, on average, for green power through utility programs. This represents a decline from previous years that can be primarily attributed to reductions in premiums or programs that protect customers from fuel cost increases.

\section{Marketing}

- As might be expected, utility expenditures on marketing and administration for green power programs vary by utility size. Utilities with more than 500,000 customers reported a wide range of marketing expenditures, with one-third spending less than $\$ 50,000$ and

\footnotetext{
${ }^{2}$ New is defined as renewable resources placed in service or repowered after January 1, 1997, consistent with the definition used by the Green-e certification program http://www.green-e.org/what is/standard/standard.html and other programs such as the Environmental Protection Agency's Green Power Partnership.
} 
about 55\% spending more than $\$ 100,000$. Only six utilities reported spending more than $\$ 250,000$ on marketing.

- Utilities reported a median cost of $\$ 25$ for acquiring new residential customers, down from $\$ 30$ reported in previous years. The top performers ${ }^{3}$ reported similar costs.

- Fewer than half of utilities reported that nonparticipants pay some portion of green pricing program costs, down from two-thirds in 2004. The most common reason cited is that the utility spreads some of the marketing and administrative costs among all ratepayers.

- On average, utilities used at least five different marketing techniques to publicize their green pricing program in 2005, while the top performers used an average of eight.

- The marketing techniques that utilities ranked as most effective include bangtails, ${ }^{4}$ community challenges, bill inserts, door-to-door marketing, direct sales (to commercial accounts), direct mail, and publicity. As in the past, the techniques that received the highest scores for effectiveness from program managers are not necessarily the most commonly used.

\section{Program Implementation}

- Utilities ranked the following as among the most effective enrollment methods: mail-in cards, check boxes on the utility bill, and other strategies (enrolling customers through account representatives, retail partners, or phone contractors).

- Fewer than one-third of utilities impose a minimum subscription requirement on their green pricing customers, with one year being the most common contract requirement.

- Just more than half of utilities reported that they had conducted customer research to aid in the design or implementation of their green pricing programs; but only one-third of utilities reported performing a program evaluation, compared to about $60 \%$ of the top performers.

- It is more common for top-performing utilities to provide additional program benefits, such as recognizing business customers in local media, recognizing other customers with plaques, providing decals for display in store windows, providing discounts or promotions at local businesses, protecting customers from fuel cost increases, and providing energy efficiency products. The top performers reported providing an average of six such benefits to program participants compared to three for all programs.

\footnotetext{
${ }^{3}$ The top performers are defined as those that were among the top 10 programs for customer participants, green power sales, and customer participation rate, according to the NREL rankings (see Appendix C).

${ }^{4}$ Bangtails are advertisements that are attached to mail-in envelopes; they must be ripped off the envelope before it can be placed in the mail.
} 


\section{Introduction}

Utilities first began offering consumers a choice of purchasing electricity generated from renewable energy sources in the early 1990s. Since then, the number of U.S. utilities offering green pricing programs has steadily grown. Today, more than 600 utilities - or about $20 \%$ of all utilities nationally - offer their customers green power options. Because some of these utilities offer programs in conjunction with cooperative associations or other public power entities, the number of distinct programs is about 130. Through these programs, more than 50 million customers have the ability to purchase renewable energy to meet some portion or all of their electricity needs, or make contributions to support the development of renewable energy resources. Typically, customers must pay a premium above standard electricity rates for this service.

Since 1999, the National Renewable Energy Laboratory (NREL) has compiled data on utility green pricing programs on an annual basis. Initially, the data covered consumer response and program-design features, such as participation and retention rates, price premiums, program structures, enrollment requirements, and new renewable energy capacity installed to supply green pricing programs. ${ }^{5}$ Beginning in 2002, NREL added data on marketing and program implementation, covering areas such as customer-acquisition costs, marketing strategies and budgets, program-evaluation efforts, procurement of supplies, and methods of enrolling and providing value to customers.

In 2004 and 2005, the data collection efforts were expanded to include utility programs implemented in conjunction with independent marketers in restructured electricity markets. Because of significant differences in the design and implementation of these programs, data on programs offered in restructured markets are only included in estimates of total sales and customers, except as noted. All other data on pricing, program design, marketing, and implementation are for utility programs offered in traditionally regulated electricity markets only, which we refer to as "green pricing." The 2002, 2003, and 2004 data are presented in detail in Bird et al. (2004), Bird and Cardinal (2004), and Bird and Brown (2005), respectively.

This report presents detailed data on utility green pricing programs compiled for year-end 2005, and examines trends in consumer response and program implementation since 1999. The data provided in this report can also be used by utilities to benchmark the success of their green pricing programs. It is important to note that this report covers only a portion of voluntary markets for renewable energy. It does not cover green power sold by independent renewable energy marketers except for cases in which the marketers work in conjunction with utilities. ${ }^{6}$

\section{Data Collection and Methodology}

The information presented in this report is based on data provided to NREL by utilities operating green power programs. In 2005, a questionnaire was distributed via e-mail to 140 green power program managers representing 129 individual green power programs (see Appendix A for the

\footnotetext{
${ }^{5}$ The results are summarized in Swezey and Bird 1999; 2000.

${ }^{6}$ For data on the entire voluntary renewable energy market, see Bird and Swezey $2005 \mathrm{a}$.
} 
questionnaire and Appendix B for a list of utilities that offer green pricing programs). In a few instances, the questionnaire was distributed to several distribution utilities that participate in a single green pricing program offered through a generation and transmission cooperative or public power supplier. This was done because some power suppliers do not collect data from participating distribution utilities or are not able to provide data on marketing and program implementation. As in 2004, data were collected from a number of utility programs that are offered in conjunction with third-party marketers in states that have implemented retail competition. These responses were only included in the estimates of total utility green power customers and sales. Responses were received for 99 programs (93 in regulated markets, and 6 in competitive markets), yielding an overall active program response rate of $71 \%$. The response rate, excluding programs offered in competitive electricity markets, was $70 \%$. Where possible, data gaps were filled with information obtained from utility Web sites, follow-up phone calls, and published reports (Washington CTED/UTC 2005), as well as data received in previous years.

\section{Customer Participation}

\section{Number of Customers}

At the end of 2005, more than 450,000 customers were participating in utility green power programs nationally, including programs offered in regulated and restructured electricity markets (Table 1). ${ }^{7}$ As in the past, a relatively small number of green power programs account for the majority of customers, with just 10 programs accounting for $65 \%$ of all participants (Appendix C). ${ }^{8}$

Table 1: Number of Participants in Utility Green Power Programs (in Regulated and Competitive Electricity Markets)

\begin{tabular}{|c|c|c|c|}
\hline & 2004 & 2005 & \% Change \\
\hline Utility Green Pricing Programs in Regulated Markets & 331,800 & 394,700 & $19 \%$ \\
\hline Utility Programs in Restructured Electricity Markets & 29,400 & 60,800 & $107 \%$ \\
\hline Total & 361,200 & 455,500 & $26 \%$ \\
\hline
\end{tabular}

The number of customers participating in utility/marketer programs in restructured electricity markets more than doubled during 2005. These programs differ from utility programs offered in traditionally regulated electricity markets in that they involve independent marketers working in conjunction with the incumbent utilities (or default service providers) to offer renewable energy products to retail consumers. Under these programs, customers can purchase green power without switching from default or standard offer service. Examples include the Connecticut CleanEnergyOptions program and the National Grid GreenUp program. In general, these

\footnotetext{
${ }^{7}$ NREL obtained consumer response data for about $70 \%$ of utility green pricing programs in 2005 , including all of the major programs. The remaining programs, which are smaller in size, do not have a large impact on overall participant numbers.

${ }^{8}$ NREL issues four different Top 10 lists based on total sales of renewable energy to program participants, total number of customer participants, customer participation rates, and the premium charged to support new renewables development. These lists can be found at http://www.eere.energy.gov/greenpower/markets/pricing.shtml?page=3.
} 
programs are relatively young, which may partially explain the high growth rates. Furthermore, the fact that these programs are primarily promoted by companies specializing in renewable energy marketing and financially vested in the success of the programs may also explain their rapid growth.

Table 2 presents the number of customers participating in utility green pricing programs offered in traditionally regulated electricity markets since 1999. From 1999 to 2005, the number of customer participants increased nearly sixfold, with growth rates during the past several years ranging from $16 \%$ to $25 \%$.

Table 2: Estimated Cumulative Number of Customers Participating in Utility Green Pricing Programs (Regulated Electricity Markets Only)

\begin{tabular}{|l|c|c|c|r|r|r|r|}
\hline Customer Segment & $\mathbf{1 9 9 9}$ & $\mathbf{2 0 0 0}$ & \multicolumn{1}{|c|}{$\mathbf{2 0 0 1}$} & $\mathbf{2 0 0 2}$ & \multicolumn{1}{c|}{$\mathbf{2 0 0 3}$} & \multicolumn{1}{c|}{$\mathbf{2 0 0 4}$} & \multicolumn{1}{c|}{$\mathbf{2 0 0 5}$} \\
\hline Residential & $\mathrm{n} / \mathrm{a}^{*}$ & 131,000 & 166,300 & 224,500 & 258,700 & 323,700 & 383,400 \\
\hline Nonresidential & $\mathrm{n} / \mathrm{a}^{*}$ & 1,700 & 2,500 & 3,900 & 6,500 & 8,100 & 11,300 \\
\hline Total & 66,900 & 132,700 & 168,800 & 228,400 & 265,000 & 331,800 & 394,700 \\
\hline$\%$ Total Annual Growth & $\mathrm{n} / \mathrm{a}$ & $98 \%$ & $27 \%$ & $35 \%$ & $16 \%$ & $25 \%$ & $19 \%$ \\
\hline$\%$ Residential Growth & $\mathrm{n} / \mathrm{a}$ & $\mathrm{n} / \mathrm{a}$ & $27 \%$ & $35 \%$ & $15 \%$ & $25 \%$ & $18 \%$ \\
\hline$\%$ Nonresidential Growth & $\mathrm{n} / \mathrm{a}$ & $\mathrm{n} / \mathrm{a}$ & $47 \%$ & $56 \%$ & $67 \%$ & $25 \%$ & $40 \%$ \\
\hline
\end{tabular}

Table 2 delineates residential and nonresidential customer participation in utility green pricing programs over time. The vast majority of participants are residential customers, with nonresidential customers accounting for only 3\% of all participants. During 2005, the number of residential and nonresidential customers grew at different rates, with the nonresidential sector growing by $39 \%$ and the residential sector by $18 \%$. This finding is consistent with sector-specific growth rates in previous years, with the exception of 2004 when both residential and nonresidential customers grew by about $25 \%$. This trend of increasing nonresidential purchasers is having a significant impact on overall sales volume, as the nonresidential purchasing quantities can be quite large as compared to residential purchases.

Table 3 presents summary statistics on the number of customers participating in green power programs, including programs in regulated and competitive electricity markets. The full range of utility sizes and program sizes is represented, illustrating that half of available programs in 2005 had fewer than 1,600 participants, and the top $25 \%$ of programs, or $75^{\text {th }}$ percentile (in terms of participants) had greater than 4,300 participants. While the average number of customers from 2004 to 2005 increased, the quartile distribution change illustrates an increased number of programs with fewer participants. This may reflect a larger number of programs offered by smaller utilities. 
Table 3: Number of Customer Participants by Program, 2004-2005

\begin{tabular}{|l|r|r|}
\hline & $\mathbf{2 0 0 4}$ & $\mathbf{2 0 0 5}$ \\
\hline $25^{\text {th }}$ percentile & 400 & 400 \\
\hline $50^{\text {th }}$ percentile & 1,900 & 1,600 \\
\hline $75^{\text {th }}$ percentile & 4,600 & 4,300 \\
\hline Average of all programs & 4,400 & 4,800 \\
\hline Total Respondents & 76 & 102 \\
\hline
\end{tabular}

In 2005, four programs had sold all of the green power available under the program and were no longer actively seeking new customers - this was an increase from two fully subscribed programs in 2004. Three of these programs maintain waiting lists.

\section{Participation Rates}

At the end of 2005, the average rate of participation in utility green pricing programs among eligible utility customers was $1.5 \%$, with a median of $1.0 \%$ (Table 4 and Table 5), These industry-wide rates have shown very little change in recent years. The 10 programs with the highest participation rates achieved participation rates of between $5 \%$ and $14 \%$ in 2005 , compared to 3\% to $6 \%$ in 2002 (Appendix C). ${ }^{9}$ Although the upper end of the range remains above $10 \%$, average participation rates remain well below penetration rates predicted by utility market research surveys (Farhar 1999).

Some possible explanations for the lack of improvement in overall participation rates include: 1) a general lack of awareness among customers, 2) lack of sustained marketing efforts on the part of some utilities, 3) a discrepancy between what customers report in surveys and what they actually do when presented with an option, 4) poor value propositions or product quality, and 5) the addition of new programs each year, which are averaged with the performance of more established programs (Holt and Holt 2004, Swezey and Bird 2001).

Table 4: Customer Participation Rates in Utility Green Pricing Programs

\begin{tabular}{|l|c|c|c|c|c|c|c|}
\hline $\begin{array}{l}\text { Participation } \\
\text { Rate }\end{array}$ & $\mathbf{1 9 9 9}$ & $\mathbf{2 0 0 0}$ & $\mathbf{2 0 0 1}$ & $\mathbf{2 0 0 2}$ & $\mathbf{2 0 0 3}$ & $\mathbf{2 0 0 4}$ & $\mathbf{2 0 0 5}$ \\
\hline Average & $0.9 \%$ & $1.2 \%$ & $1.3 \%$ & $1.2 \%$ & $1.2 \%$ & $1.3 \%$ & $1.5 \%$ \\
\hline Median & $0.8 \%$ & $0.7 \%$ & $0.7 \%$ & $0.8 \%$ & $0.9 \%$ & $1.0 \%$ & $1.0 \%$ \\
\hline $\begin{array}{l}\text { Top } 10 \\
\text { programs }\end{array}$ & $2.1 \%-$ & $2.6 \%-$ & $3.0 \%-$ & $3.0 \%-$ & $3.9 \%-$ & $3.8 \%-$ & $4.6 \%-$ \\
\hline "Data for April 2000 & $4.7 \%{ }^{*}$ & $7.3 \%$ & $7.0 \%$ & $5.8 \%$ & $11.1 \%$ & $14.5 \%$ & $13.6 \%$ \\
\hline
\end{tabular}

\footnotetext{
${ }^{9}$ From 2000 to 2002, the high end of the range declined because the utility with the highest participation rate (Moorhead Public Service) experienced an increase in its overall customer base, while the number of participants in its green pricing program remained steady. The program was fully subscribed in 2000 , and the utility has not attempted to expand it. Likewise, the high end of the range declined from 2004 to 2005, because the number of participants in the Lenox Municipal Utilities green power program essentially remained constant, while its customer base increased.
} 
Table 5: Customer Participation Rates in Utility Green Pricing Programs, 2004-2005

\begin{tabular}{|l|c|c|}
\hline Participation Rate & $\mathbf{2 0 0 4}$ & $\mathbf{2 0 0 5}$ \\
\hline $25^{\text {th }}$ Percentile & $0.3 \%$ & $0.4 \%$ \\
\hline $50^{\text {th }}$ Percentile (Median) & $1.0 \%$ & $1.0 \%$ \\
\hline $75^{\text {th }}$ Percentile & $1.4 \%$ & $1.8 \%$ \\
\hline
\end{tabular}

Table 6 shows that across all utilities, the average participation rate for green pricing programs in 2005 for residential and nonresidential customers was $1.6 \%$ and $0.7 \%$, respectively. Median participation rates were $1.2 \%$ and $0.2 \%$, respectively (Table 7 ). The lower participation rates among nonresidential customers may be explained, in part, by the fact that some programs place less emphasis on the nonresidential sector. Also, nonresidential customers as a whole may be more price-sensitive and perhaps less willing to pay a premium than residential consumers.

Table 6 reveals slight differences in average participation rates among programs offered by investor-owned utilities (IOUs), municipal or public utilities, and cooperatives. Although IOU participation rates have increased over time, IOUs still reported the lowest average participation rates among all utility types. However, the differences diminish or disappear when the median rates are compared.

Table 6: Average Green Pricing Participation Rates by Utility Type

\begin{tabular}{|c|c|c|c|c|c|c|c|c|c|c|c|c|}
\hline \multirow[t]{2}{*}{$\begin{array}{l}\text { Utility } \\
\text { Type }\end{array}$} & \multicolumn{3}{|c|}{$\begin{array}{l}\text { Number of } \\
\text { Responses }\end{array}$} & \multicolumn{3}{|c|}{$\begin{array}{c}\text { Residential } \\
\text { Customers } \\
\text { Average (\%) }\end{array}$} & \multicolumn{3}{|c|}{$\begin{array}{l}\text { Nonresidential } \\
\text { Customers } \\
\text { Average (\%) }\end{array}$} & \multicolumn{3}{|c|}{$\begin{array}{c}\text { All Customers } \\
\text { Average (\%) }\end{array}$} \\
\hline & '03 & '04 & '05 & '03 & '04 & '05 & '03 & ‘04 & '05 & '03 & ‘04 & '05 \\
\hline All Utilities & 75 & 80 & 89 & 1.4 & 1.4 & 1.6 & 0.5 & 0.4 & 0.7 & 1.2 & 1.3 & 1.5 \\
\hline Co-ops & 13 & 13 & 17 & 1.7 & 1.7 & 1.7 & 0.6 & 0.6 & 0.7 & 1.6 & 1.5 & 1.5 \\
\hline Public & 36 & 38 & 45 & 1.5 & 1.6 & 1.7 & 0.5 & 0.5 & 0.9 & 1.3 & 1.4 & 1.6 \\
\hline $\begin{array}{l}\text { Investor- } \\
\text { owned }\end{array}$ & 26 & 29 & 27 & 1.0 & 1.1 & 1.3 & 0.3 & 0.3 & 0.3 & 0.8 & 1.0 & 1.2 \\
\hline
\end{tabular}

Table 7: Median Green Pricing Participation Rates by Utility Type

\begin{tabular}{|l|c|c|c|c|c|c|c|c|c|c|c|c|}
\hline & \multicolumn{3}{|c|}{$\begin{array}{l}\text { Number of } \\
\text { Utility } \\
\text { Type }\end{array}$} & \multicolumn{3}{|c|}{$\begin{array}{c}\text { Responses } \\
\text { Customers } \\
\text { Median (\%) }\end{array}$} & \multicolumn{3}{c|}{$\begin{array}{c}\text { Nonresidential } \\
\text { Customers } \\
\text { Median (\%) }\end{array}$} & \multicolumn{3}{c|}{$\begin{array}{c}\text { All Customers } \\
\text { Median (\%) }\end{array}$} \\
\hline & '03 & '04 & '05 & '03 & '04 & '05 & '03 & '04 & '05 & '03 & '04 & '05 \\
\hline All Utilities & 75 & 80 & 89 & 1.0 & 1.1 & 1.2 & 0.2 & 0.2 & 0.2 & 0.9 & 1.0 & 1.0 \\
\hline Co-ops & 13 & 13 & 17 & 1.1 & 1.2 & 1.2 & 0.01 & 0.1 & 0.3 & 1.0 & 1.0 & 1.0 \\
\hline Public & 36 & 38 & 45 & 1.1 & 1.1 & 1.1 & 0.2 & 0.2 & 0.2 & 0.2 & 0.8 & 1.0 \\
\hline $\begin{array}{l}\text { Investor- } \\
\text { owned }\end{array}$ & 26 & 29 & 27 & 0.9 & 1.0 & 1.2 & 0.1 & 0.1 & 0.1 & 0.7 & 0.9 & 1.0 \\
\hline
\end{tabular}




\section{Retention of Customers}

In 2005, utilities reported that an average of $6.5 \%$ and a median $5.1 \%$ of customers dropped out of green pricing programs, reversing the trend of increasing rates during the past several years (Table 8). This finding is somewhat surprising in a year in which customers throughout the country faced higher electricity and energy prices. Although the reason for the improvement in customer retention is not clear, this finding suggests that customers tend to be "sticky" and maintain participation in green power programs, despite other cost increases.

Historically, utilities that have reported higher-than-average turnover rates among green power customers cite high turnover among all utility customers; for example, several of these utilities have service territories that include large universities where high customer turnover is recurrent. One utility also cited particularly high attrition rates after announcing plans to build a new coalfired power plant, which regional environmental organizations opposed. And a few utilities have experienced higher-than-average decreases in enrollment as a result of general rate increases.

One effective strategy for reducing attrition is retaining customer participants in the program when they move within the utility service territory. Also, continuing to communicate the success and benefits of the program to consumers may help alleviate problems with attrition. Consumers may need to be reminded periodically of the value of the program and the impact that their expenditures have had. Finally, offering benefits such as exempting customers from fossil fuel cost increases may help retain customers.

Table 8: Fraction of Customers Dropping Out of Green Pricing Programs

\begin{tabular}{|r|r|r|r|r|}
\hline & $\mathbf{2 0 0 2}$ & $\mathbf{2 0 0 3}$ & $\mathbf{2 0 0 4}$ & $\mathbf{2 0 0 5}$ \\
\hline Median & $2.5 \%$ & $6.6 \%$ & $8.8 \%$ & $5.1 \%$ \\
\hline Average & $4.3 \%$ & $7.1 \%$ & $9.8 \%$ & $6.5 \%$ \\
\hline
\end{tabular}

\section{Renewable Energy Sales and Supplies}

\section{Green Power Sales and Revenues}

Collectively, utilities sold nearly 3 billion kilowatt-hours (kWh), or about 313 average megawatts (aMW), of green power to customers in 2005 (Table 9). Sales of renewable energy through utility programs in competitive electricity markets more than doubled during 2005 . The fact that these programs are implemented in conjunction with competitive marketers specializing in renewable energy marketing - and that many are relatively young - may explain the significantly higher growth rates.

The 10 top-performing green pricing programs represented $71 \%$ of total sales, with one program (Austin Energy) accounting for 16\% of all sales (Appendix C). Austin Energy's sales success stems from the fact that it allows customers to lock in the price of green energy at a fixed rate for up to 10 years, which has been particularly popular among nonresidential customers. Overall, 
nonresidential customers represented about 3\% of customers, but represented about one-third of total program sales.

Table 9: Sales of Renewable Energy through Utility Green Power Programs in Regulated and Competitive Electricity Markets (million kWh)

\begin{tabular}{|l|r|r|r|}
\hline & $\mathbf{2 0 0 4}$ & $\mathbf{2 0 0 5}$ & \% Change \\
\hline Utility Green Pricing Programs in Regulated Markets & 1,839 & 2,448 & $33 \%$ \\
\hline Utility Programs in Competitive Electricity Markets & 136 & 291 & $114 \%$ \\
\hline Total & 1,975 & 2,738 & $39 \%$ \\
\hline
\end{tabular}

Table 10 presents sales of renewable energy through utility green pricing programs in regulated electricity markets over time. Green pricing program sales to all customer classes grew by $33 \%$ in 2005, compared to rates in excess of $40 \%$ during the past several years. The growth in sales can be attributed to the larger number of customers purchasing green power as well as larger purchases by nonresidential customers (Table 11). On average, residential customers purchased an average of about 4,200 kWh of green power annually in 2005, while nonresidential customers purchased nearly $75,000 \mathrm{kWh} .{ }^{10}$ Average purchases by residential customers have increased substantially since 2001 from $2,400 \mathrm{kWh}$ per year to $4,200 \mathrm{kWh}$ per year. This increase is likely due to a larger number of programs that require customers to purchase green power for $100 \%$ or a more substantial fraction of their electricity use, as well as decreases in the price of green power.

Table 10: Annual Sales of Green Energy through Utility Green Pricing Programs (Regulated Electricity Markets Only), millions of kWh

\begin{tabular}{|l|r|r|r|r|r|r|}
\hline & $\mathbf{2 0 0 0}$ & $\mathbf{2 0 0 1}$ & $\mathbf{2 0 0 2}$ & $\mathbf{2 0 0 3}$ & $\mathbf{2 0 0 4}$ & $\mathbf{2 0 0 5}$ \\
\hline Sales to Residential Customers & $*$ & 400 & 661 & 874 & 1,295 & 1,606 \\
\hline Sales to Nonresidential Customers & $*$ & 173 & 234 & 410 & 544 & 842 \\
\hline Total Sales to All Customers & 454 & 573 & 895 & 1,284 & 1,839 & 2,448 \\
\hline$\%$ Annual Growth in Total Sales & $*$ & $26 \%$ & $56 \%$ & $43 \%$ & $43 \%$ & $33 \%$ \\
\hline$\%$ Nonresidential of Total Sales & $*$ & $30 \%$ & $26 \%$ & $32 \%$ & $30 \%$ & $34 \%$ \\
\hline *Sales information for customer segments not available for 2000.
\end{tabular}

Table 11: Average Purchases of Green Energy Per Green Pricing Customer (kWh/year)

\begin{tabular}{|l|r|r|r|r|r|}
\hline & $\mathbf{2 0 0 1}$ & $\mathbf{2 0 0 2}$ & $\mathbf{2 0 0 3}$ & $\mathbf{2 0 0 4}$ & $\mathbf{2 0 0 5}$ \\
\hline Residential Customers & 2,400 & 2,900 & 3,400 & 4,000 & 4,200 \\
\hline Nonresidential Customers & 69,200 & 60,000 & 63,100 & 67,200 & 74,500 \\
\hline All Customers & 3,400 & 3,900 & 4,800 & 5,500 & 6,200 \\
\hline
\end{tabular}

\footnotetext{
${ }^{10}$ Note that estimates of average purchases have been revised for years 2002 to 2004 for those reported in Bird and Brown (2004), which were averaged across utility programs. Estimates presented here are calculated based on total sales and customer participants.
} 
Table 12 presents the summary statistics for the kilowatt-hour sales of renewable energy through utility programs in regulated and competitive markets. In 2005, 25\% of programs sold more than 26 million $\mathrm{kWh}$ of green power annually, while half sold more than 4 million $\mathrm{kWh}$. The increase in the average, and the decrease in the quartile values between 2004 and 2005, indicate an increasing number of smaller programs responding.

Table 12: Renewable Energy Sales through Utility Programs (million kWh)

\begin{tabular}{|l|r|r|}
\hline & $\mathbf{2 0 0 4}$ & $\mathbf{2 0 0 5}$ \\
\hline $25^{\text {th }}$ percentile & 0.8 & 0.7 \\
\hline $50^{\text {th }}$ percentile & 5.5 & 4.4 \\
\hline $75^{\text {th }}$ percentile & 21.5 & 26.1 \\
\hline Average & 25.0 & 29.1 \\
\hline Total Respondents & 74 & 94 \\
\hline
\end{tabular}

\section{Renewable Energy Resources Supplying Green Pricing Programs}

Most programs use new renewable energy sources to supply their green pricing programs, with $87 \%$ of sales supplied from new renewable energy facilities. ${ }^{11}$ Of total sales, wind resources supplied $76 \%$, followed by biomass including landfill gas (17\%), hydro (4\%), geothermal (3\%), and solar $(0.2 \%)$ (Table 13). Despite the relative contribution to total sales, wind, solar, and landfill gas are the renewable resources most commonly used to supply green pricing programs. For example, many utilities offer products that include some solar, but the contribution of solar to the total green power program resource mix on a generation basis is generally small.

Renewable energy sold through green pricing programs in 2005 represents an equivalent renewable energy capacity of nearly $800 \mathrm{MW}$, with more than $740 \mathrm{MW}$ of this represented by new renewable energy resources. ${ }^{12}$ Wind energy represents nearly $90 \%$ of the total capacity supplying green pricing programs.

Table 13: Renewable Energy Sources Supplying Green Pricing Programs, 2005

\begin{tabular}{|l|r|r|r|r|r|r|r|r|}
\hline & $\begin{array}{c}\text { Landfill } \\
\text { Gas }\end{array}$ & Digesters & Wood & $\begin{array}{c}\text { Geother } \\
\text {-mal }\end{array}$ & Hydro & \multicolumn{1}{c|}{ Solar } & \multicolumn{1}{c|}{ Wind } & \multicolumn{1}{c|}{ Total } \\
\hline Sales MWh & 323,000 & 28,000 & 63,000 & 72,000 & 97,000 & 6,000 & $1,859,000$ & $2,448,000$ \\
\hline$\%$ of Total Sales & $13.2 \%$ & $1.2 \%$ & $2.6 \%$ & $2.9 \%$ & $3.9 \%$ & $0.2 \%$ & $76.0 \%$ & $100 \%$ \\
\hline \% New & $59 \%$ & $100 \%$ & $88 \%$ & $4 \%$ & $12 \%$ & $100 \%$ & $99 \%$ & $87.3 \%$ \\
\hline Capacity Factor & $90 \%$ & $90 \%$ & $80 \%$ & $90 \%$ & $50 \%$ & $20 \%$ & $30 \%$ & $\mathrm{n} / \mathrm{a}$ \\
\hline Total MW & 41.0 & 3.6 & 9.0 & 9.1 & 22.0 & 3.4 & 707.4 & 795.5 \\
\hline MW New RE & 24.1 & 3.6 & 7.9 & 0.3 & 2.6 & 3.4 & 701.7 & 743.7 \\
\hline
\end{tabular}

\footnotetext{
${ }^{11}$ New is defined as renewable resources placed in service or repowered after January 1, 1997, consistent with the definition used by the Green-e certification program http://www.green-e.org/what is/standard/standard.html and other programs such as the Environmental Protection Agency's Green Power Partnership.

${ }^{12}$ Capacity factors are derived from EPRI and U.S. DOE Renewable Energy Technology Characterizations, TR109496, December 1997.
} 
In previous years, capacity estimates were based on renewable energy projects used to serve green pricing programs, rather than derived from renewable energy sales. ${ }^{13}$ Therefore, the 2005 estimated capacity is not directly comparable to capacity estimates from previous years (see Table 14). However, the two approaches yield relatively consistent results.

Table 14: Estimated Cumulative Capacity Supplying Utility Green Pricing Programs, 1999-2004

\begin{tabular}{|l|c|c|c|c|c|c|}
\hline & $\mathbf{1 9 9 9}$ & $\mathbf{2 0 0 0}$ & $\mathbf{2 0 0 1}$ & $\mathbf{2 0 0 2}$ & $\mathbf{2 0 0 3}$ & $\mathbf{2 0 0 4}$ \\
\hline Cumulative MW & 68 & 77 & 221 & 279 & 510 & 706 \\
\hline Annual Growth \% & -- & $14 \%$ & $188 \%$ & $26 \%$ & $82 \%$ & $38 \%$ \\
\hline
\end{tabular}

While many programs use blends of renewable energy sources, nearly half of all programs feature only one energy source. Of those that feature one resource, most feature wind, while a handful feature solar or biomass. The remaining programs offer a blend of two or more resources.

\section{Green Energy Sales vs. Total Utility Sales}

Green energy sales still represent a small but increasing proportion of a utility company's overall energy sales. Table 15 shows that, on average, sales through green pricing programs represented about $0.5 \%$ of total utility electricity sales in 2005 , with about $0.9 \%$ of residential electricity sales and $0.2 \%$ of nonresidential electricity sales in the same year. These fractions have increased steadily during the past few years (Table 16). Half of programs reported green power sales of $0.2 \%$ of total electricity sales or more. The most successful utility programs reported green energy sales of about $4 \%$ of total retail electricity sales.

Table 15: Green Energy Sales as a Percent of Utility Electricity Sales, 2005

\begin{tabular}{|c|c|c|c|c|c|}
\hline $\begin{array}{c}\text { Customer } \\
\text { Class }\end{array}$ & Average & $\mathbf{2 5}^{\text {th }}$ Percentile & $\begin{array}{c}\text { Median } \\
\left(\mathbf{5 0}^{\text {th }} \text { Percentile }\right)\end{array}$ & $\mathbf{7 5}^{\text {th }}$ Percentile & Range \\
\hline Residential & $0.89 \%$ & $0.08 \%$ & $0.34 \%$ & $0.84 \%$ & $0 \%-13.7 \%$ \\
\hline Nonresidential & $0.23 \%$ & $0.00 \%$ & $0.04 \%$ & $0.20 \%$ & $0 \%-4.8 \%$ \\
\hline All customers & $0.48 \%$ & $0.06 \%$ & $0.2 \%$ & $0.49 \%$ & $0 \%-4.0 \%$ \\
\hline
\end{tabular}

\footnotetext{
${ }^{13}$ For details on the derivation of these estimates, see Bird and Swezey 2005b.
} 
Table 16: Average, Median, and Range Green Energy Sales as a Percent of Utility Electricity Sales

\begin{tabular}{|c|c|c|c|c|c|c|c|c|l|}
\hline & \multicolumn{3}{|c|}{2003} & \multicolumn{3}{c|}{$\mathbf{2 0 0 4}$} & \multicolumn{3}{c|}{2005} \\
\hline $\begin{array}{c}\text { Customer } \\
\text { Class }\end{array}$ & Avg. & Med. & Range & Avg. & Med. & Range & Avg. & Med. & Range \\
\hline & & & $0.0 \%-$ & & & $0 \%-$ & & & $0 \%-$ \\
Residential & $0.30 \%$ & $0.02 \%$ & $3.6 \%$ & $0.70 \%$ & $0.40 \%$ & $10.2 \%$ & $0.89 \%$ & $0.34 \%$ & $13.7 \%$ \\
\hline & & & $0.0 \%-$ & & & $0 \%-$ & & & $0 \%-$ \\
Nonresidential & $0.10 \%$ & $0.00 \%$ & $2.9 \%$ & $0.20 \%$ & $0.02 \%$ & $3.7 \%$ & $0.23 \%$ & $0.04 \%$ & $4.8 \%$ \\
\hline & & & $0.0 \%-$ & & & $0 \%-$ & & & $0 \%-$ \\
All customers & $0.20 \%$ & $0.04 \%$ & $3.2 \%$ & $0.40 \%$ & $0.20 \%$ & $3.2 \%$ & $0.48 \%$ & $0.2 \%$ & $4.0 \%$ \\
\hline
\end{tabular}

On average, residential customers spent about $\$ 4.50$ per month to purchase or support green power through utility programs in 2005, the lowest recorded average expenditures (Table 17). This decline in expenditures is primarily due to a number of programs that reduced the price of renewable energy for customer participants. In fact, this decrease in average monthly expenditure coincides with an increase in average residential purchase quantities.

Utility green pricing programs collected an estimated \$25 million in green power revenues in 2005 (Table 17). Although total renewable energy sales grew in 2005, revenues declined because a number of programs lowered the premiums charged for their green power products. Green pricing program revenues are typically used to pay the above-market costs of renewables, as well as the costs of administering and marketing the program —although the treatment of the latter differs by utility (see discussion in the Marketing section of Holt and Holt 2004, Swezey and Bird 2001).

Table 17: Residential Monthly Expenditures on Green Power and Annual Program Revenues

\begin{tabular}{|l|c|c|c|c|}
\hline & $\mathbf{2 0 0 2}$ & $\mathbf{2 0 0 3}$ & $\mathbf{2 0 0 4}$ & $\mathbf{2 0 0 5}$ \\
\hline Average monthly residential expenditures & $\$ 4.80$ & $\$ 5.50$ & $\$ 5.30$ & $\$ 4.49$ \\
\hline Annual utility revenues from green power & $\$ 15$ million & $\$ 20$ million & $\$ 32$ million & $\$ 25$ million \\
\hline
\end{tabular}

\section{Ownership vs. Purchases of Supplies}

About $25 \%$ of utilities supply their green pricing programs entirely from their own renewable energy generation facilities, compared to $21 \%$ in 2004 and 31\% in 2003 (Table 18). Another $59 \%$ of utilities either purchase all of their power from an independent power generator or purchase renewable energy certificates (RECs) from a marketer or supplier. The remaining utilities use a combination of these approaches to supply their green power programs. Generally, the data show a movement away from project ownership and an increased reliance on REC purchases. Between 2003 and 2005, the fraction of utilities that purchased RECs for all of their green pricing program supplies increased from $18 \%$ to $32 \%$. In addition, the fraction of utilities that owned their own generation for any portion of program supplies dropped. 
Also, about $9 \%$ of utilities reported using customer-owned renewable energy sources, such as customer-sited solar systems, to supply a portion of their green power program. This question was only asked in 2005 .

Table 18: Utility Procurement of Renewable Energy Supplies

\begin{tabular}{|l|c|c|c|c|c|c|c|c|c|}
\hline & \multicolumn{3}{|c|}{$\begin{array}{c}\text { Utilities that Own } \\
\text { Generation }\end{array}$} & \multicolumn{2}{c|}{$\begin{array}{c}\text { Utilities that } \\
\text { Purchase Power }\end{array}$} & \multicolumn{3}{c|}{$\begin{array}{c}\text { Utilities that } \\
\text { Purchase RECs }\end{array}$} \\
\hline Fraction of Supplies & $\mathbf{2 0 0 3}$ & $\mathbf{2 0 0 4}$ & $\mathbf{2 0 0 5}$ & $\mathbf{2 0 0 3}$ & $\mathbf{2 0 0 4}$ & $\mathbf{2 0 0 5}$ & $\mathbf{2 0 0 3}$ & $\mathbf{2 0 0 4}$ & $\mathbf{2 0 0 5}$ \\
\hline $\begin{array}{l}\text { For } 100 \% \text { of program power } \\
\text { supplies }\end{array}$ & $31 \%$ & $21 \%$ & $25 \%$ & $32 \%$ & $32 \%$ & $27 \%$ & $18 \%$ & $30 \%$ & $32 \%$ \\
\hline $\begin{array}{l}\text { For at least 50\% of program power } \\
\text { supplies }\end{array}$ & $39 \%$ & $25 \%$ & $32 \%$ & $42 \%$ & $40 \%$ & $42 \%$ & $20 \%$ & $33 \%$ & $35 \%$ \\
\hline $\begin{array}{l}\text { For any fraction of program power } \\
\text { supplies }\end{array}$ & $49 \%$ & $33 \%$ & $43 \%$ & $47 \%$ & $48 \%$ & $47 \%$ & $24 \%$ & $36 \%$ & $35 \%$ \\
\hline Note: Percentages based on 74 responding programs in 2003, 84 programs in 2004, and 80 programs in 2005. & & \\
\hline
\end{tabular}

Collectively, utilities purchased more than 1 billion kWh of RECs to serve green power customers in 2005, which represents $42 \%$ of all green power sold through utility green pricing programs (Table 19). RECs purchases grew by $46 \%$ in 2005 , down from $69 \%$ in 2004 , and $300 \%$ in 2003.

Table 19: REC Purchases by Utilities to Supply Green Pricing Programs

\begin{tabular}{|l|c|c|c|c|}
\hline & $\mathbf{2 0 0 2}$ & $\mathbf{2 0 0 3}$ & $\mathbf{2 0 0 4}$ & $\mathbf{2 0 0 5}$ \\
\hline $\begin{array}{l}\text { REC purchases by utilities for green } \\
\text { pricing programs (million kWh) }\end{array}$ & 103 & 419 & 707 & 1,030 \\
\hline $\begin{array}{l}\text { REC purchases as percent of total } \\
\text { green pricing sales }\end{array}$ & $11 \%$ & $33 \%$ & $38 \%$ & $42 \%$ \\
\hline
\end{tabular}

Data from 2005 also suggest that RECs are being used in wider geographic regions. In 2003, about three-quarters of utilities that supplied their programs with RECs were in the Pacific Northwest; in 2005, about half of the utilities using RECs were in the Pacific Northwest. Utilities that reported purchasing RECs for some portion of their program supplies in 2005 covered 10 states, including California, Colorado, Florida, Idaho, Montana, New Mexico, Oregon, Utah, Vermont, and Washington.

\section{Product Type}

Most utility green pricing programs are structured so that customers can purchase renewable energy to meet some or all of their electricity needs. The green power premium charged in these "energy-based" programs is typically expressed in $\varnothing / \mathrm{kWh}$ or $\$ / \mathrm{kWh}$ block. Other programs are structured to allow customers to contribute funds that support the development of renewable 
energy sources. These so-called "contribution programs" have become less common, and currently represent less than $10 \%$ of all programs. Finally, a few utilities have offered programs through which customers make a monthly payment tied to the amount of renewable energy capacity that is supported ("capacity-based programs"). For example, customers might be offered the option to pay $\$ 6$ each month to support 100 watts of solar energy-generating capacity. Capacity-based programs are no longer actively marketed and, in some cases, have been phased out in favor of energy-based or contribution programs.

\section{Energy Blocks vs. Percentage of Use}

About two-thirds of energy-based programs are structured so that customers can purchase blocks of green power. Block sizes range from $15 \mathrm{kWh}$ (for energy derived exclusively from solar systems) to $1,000 \mathrm{kWh}$ (for wind energy or renewable energy blends). The most common block size offered to residential customers is $100 \mathrm{kWh}$. Many utilities offer larger block sizes to nonresidential customers, and some offer customers the option of purchasing green power for all of their electricity use.

The remaining programs allow customers to purchase green power for some fraction of their electricity needs. Most of these programs allow residential customers to elect to have $25 \%, 50 \%$, or $100 \%$ of their electricity supplied from renewable sources, while a few offer fractions as small as $10 \%$. Often, commercial and industrial customers can purchase green power for a smaller fraction of their electricity use.

Regarding the question of whether it is better to offer a percent-of-use option or kWh-blocks, some marketers have argued that it is difficult to communicate the concept of a kWh-block to consumers, because customers do not understand $\mathrm{kWh}$ and are not used to thinking about them. Some marketers have found that this is a significant barrier to enrolling customers. They argue that consumers can more easily understand a product that is presented as a percentage of electricity use. On the other hand, selling blocks of renewable energy may provide additional flexibility to consumers to enable them to purchase smaller increments (although this could also be accomplished by offering a small percent-of-use option). Another potential benefit for customers of purchasing blocks is that the green power premium remains fixed for the customer each month and does not vary along with electricity consumption.

A statistical analysis of green pricing data found that utilities that offer larger blocks (at least 200 $\mathrm{kWh}$ ) or higher percentages (at least $25 \%$ ) tend to have greater sales to residential customers, with no obvious impact on the overall level of customer participation (Wiser et al. 2004). In other words, customers may be willing to purchase higher quantities of renewable energy, if that is what is required to participate in the program. However, this effect may not hold for very high purchase thresholds. 


\section{Pricing}

In 2005, price premiums for energy-based programs ranged from $-0.67 \phi / \mathrm{kWh}$ to $17.6 \phi / \mathrm{kWh}$, with an average premium of $2.36 \notin / \mathrm{kWh}$ and a median of $2 \notin / \mathrm{kWh}$. Figure 1 displays price

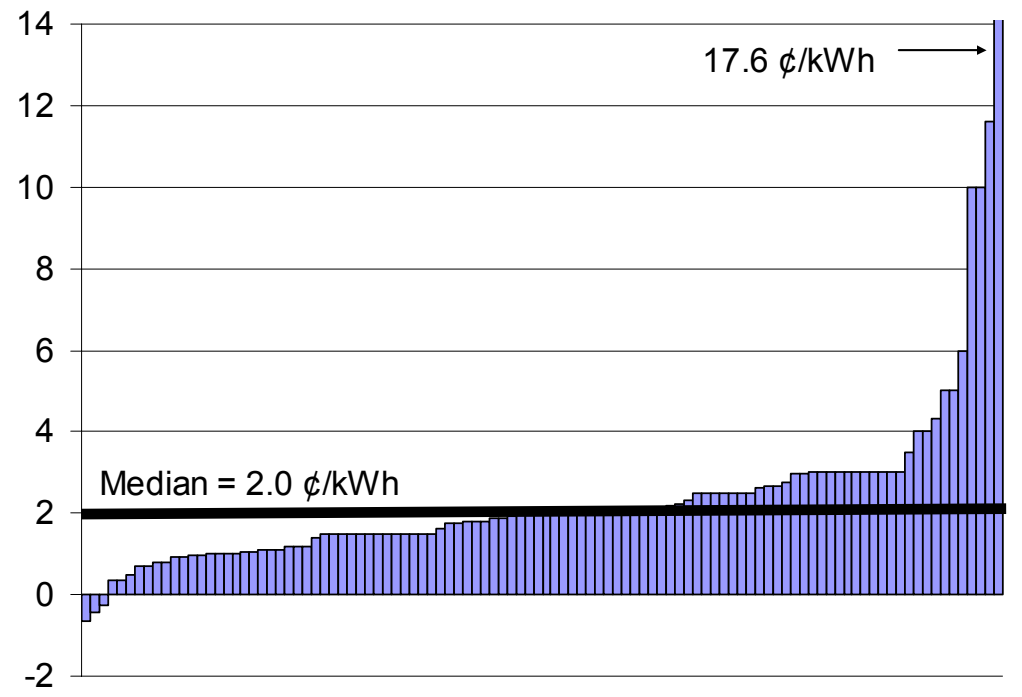

Figure 1: Utility Green Pricing Program Premiums (Energy-Based Programs Only) premiums for individual utility programs - solar-based products dominate the high end of the price range. In 2005 , the utility programs with the lowest premiums for energy derived from new renewable sources had premiums ranging from $-0.67 \notin / \mathrm{kWh}$ to $0.91 \not / \mathrm{kWh}$.

In 2005, price premiums continued to decline, decreasing about $4 \%$ from 2004. Since 2000, the average price premium has dropped at an average annual rate of about $7.5 \%$. The median premium remained at $2.0 \notin / \mathrm{kWh}$ between 2004 and 2005 (Table 20).

Table 20: Price Premiums of Utility Green Power Products $(\phi / k W h)$

\begin{tabular}{|c|c|c|c|c|c|c|c|}
\hline & 1999 & 2000 & 2001 & 2002 & 2003 & 2004 & 2005 \\
\hline Average Premium & 2.15 & 3.48 & 2.93 & 2.82 & 2.62 & 2.45 & 2.36 \\
\hline Median Premium & 2.00 & 2.50 & 2.50 & 2.50 & 2.00 & 2.00 & 2.00 \\
\hline Range of Premiums & $4-5.0$ & $.5)-20.0$ & $.9-17.6$ & $.7-17.6$ & $0.6-17.6$ & $.33-17.6$ & $(0.67)-17.6$ \\
\hline $\begin{array}{l}10 \text { Programs with } \\
\text { Lowest Premiums }\end{array}$ & $0.4-2.5^{\star *}$ & $(0.5)-2.5$ & $1.0-1.5$ & $0.7-1.5$ & $0.6-1.3$ & $0.33-1.0$ & $(0.67)-0.91$ \\
\hline $\begin{array}{l}\text { Number of Programs } \\
\text { Represented }\end{array}$ & 24 & 50 & 60 & 80 & 91 & 101 & 104 \\
\hline \multicolumn{8}{|c|}{$\begin{array}{l}{ }^{*} \text { Represents the } 10 \text { utility programs with the lowest price premiums for new customer-driven renewable energy. This includes only programs } \\
\text { that have installed - or announced firm plans to install or purchase power from - new renewable energy sources. In } 2001 \text {, the discrepancy } \\
\text { between the low end of the range for all programs and the top } 10 \text { programs results from the program with the lowest premium (0.9ф/kWh) } \\
\text { not being eligible for the top 10, because it was either selling some existing renewables or had not installed any new renewable capacity for } \\
\text { its program. }\end{array}$} \\
\hline
\end{tabular}

During 2005, 10 programs modified the price premium charged for green power, with most resulting in a premium decrease. Programs with fuel adjustment exemptions had changes in premium paid, and several programs made minor adjustments to the structure of their premiums that had little impact on the size of the premium paid. 
For those utilities that reduced their premiums, most attributed the reduction to the exemption of green power customers from fossil fuel charges or their ability to renegotiate power purchase contracts at lower rates. Other reasons that have contributed to the decline in premiums over time are the availability of state or federal financial incentives, higher than expected capacity factors, and natural gas price increases, which have reduced the cost spread between renewable energy and gas-fired generation.

Table 21 presents green pricing premiums by utility type for the past several years, while additional data on premiums in 2005 are shown in Table 22. IOUs have the highest average price premium at $3.09 \notin / \mathrm{kWh}$, while cooperatives and public utilities have lower average premiums at $1.90 \notin / \mathrm{kWh}$ and $2.20 \phi / \mathrm{kWh}$, respectively. Some of the differences among utility types may result from a greater tendency of IOUs to include program administration and marketing costs in the premium, or to seek recovery of program costs over a shorter period of time. The higher average premium calculated for investor-owned utilities may also stem from the fact that several IOUs offer solar-based programs with relatively high premiums, on the order of $10 \notin / \mathrm{kWh}$ or higher.

Table 21: Green Pricing Premiums by Utility Type, 2003-2005 $(\phi / k W h)$

\begin{tabular}{|l|c|c|c|c|c|c|c|c|c|}
\hline & \multicolumn{3}{|c|}{2003} & \multicolumn{3}{c|}{2004} & \multicolumn{3}{c|}{2005} \\
\hline $\begin{array}{c}\text { Type of } \\
\text { Utility }\end{array}$ & Avg. & Med. & Range & Avg. & Med. & Range & Avg. & Med & Range \\
\hline $\begin{array}{l}\text { Investor- } \\
\text { owned }\end{array}$ & 3.36 & 2.04 & $\begin{array}{c}0.6- \\
17.6\end{array}$ & 3.14 & 2.00 & $\begin{array}{c}0.3- \\
17.6\end{array}$ & 3.09 & 1.92 & $\begin{array}{c}(0.67)- \\
17.6\end{array}$ \\
\hline Public & 2.30 & 2.00 & $\begin{array}{c}0.6- \\
11.6\end{array}$ & 2.24 & 2.00 & $\begin{array}{c}0.5- \\
11.6\end{array}$ & 2.20 & 2.00 & $\begin{array}{c}(0.45)- \\
11.60\end{array}$ \\
\hline Co-op & 2.34 & 2.50 & $\begin{array}{c}0.9- \\
3.5\end{array}$ & 2.00 & 1.85 & $\begin{array}{c}0.5- \\
3.5\end{array}$ & 1.90 & 1.90 & $\begin{array}{c}0.50- \\
3.50\end{array}$ \\
\hline All Utilities & 2.62 & 2.00 & $\begin{array}{c}0.6- \\
17.6\end{array}$ & 2.45 & 2.00 & $\begin{array}{c}0.3- \\
17.6\end{array}$ & 2.36 & 2.00 & $\begin{array}{c}0.67)- \\
17.6\end{array}$ \\
\hline
\end{tabular}

Table 22: Green Pricing Premiums by Utility Type, 2005 ( $\phi / k W h)$

\begin{tabular}{|l|c|c|c|c|c|}
\hline Type of Utility & Average & $\begin{array}{c}\mathbf{2 5}^{\text {th }} \\
\text { Percentile }\end{array}$ & Median & $\begin{array}{c}\mathbf{7 5}^{\text {th }} \\
\text { Percentile }\end{array}$ & Range \\
\hline Investor-owned & 3.09 & 0.98 & 1.92 & 3.21 & $(0.67)-17.6$ \\
\hline Public & 2.20 & 1.50 & 2.00 & 2.74 & $(0.45)-11.60$ \\
\hline Co-op & 1.90 & 1.50 & 1.90 & 2.50 & $0.50-3.50$ \\
\hline All Utilities & 2.36 & 1.40 & 2.00 & 2.65 & $(0.67)-17.6$ \\
\hline
\end{tabular}


About 10 programs offer lower green energy premiums to nonresidential customers, offering bulk purchase discounts for large green power purchasers. ${ }^{14}$ In these programs, the premium charged to nonresidential customers is generally about $0.5 \phi / \mathrm{kWh}$ to $2 \phi / \mathrm{kWh}$ less than the residential green energy premium.

Because most renewable energy facilities do not rely on fuel, some utilities offer fixed-price green power products or exempt their green power customers from some fuel-cost charges. A number of utilities include this feature as a component of their green pricing product. ${ }^{15}$ One of these utilities also exempts green power customers from the costs associated with making environmental improvements at some of its fossil fuel-generating facilities. Exempting customers from fossil fuel costs can be a particularly important strategy for enrolling large nonresidential customers with larger energy needs, as evidenced by the success of Austin Energy, which accounts for nearly $16 \%$ of all utility green pricing sales nationwide.

\section{Marketing}

\section{Marketing and Administration Spending}

As one might expect, spending on marketing and administration for green power programs generally varies with size of the utility; however, some large utilities spend relatively little on marketing. In 2005, about three-quarters of the utilities serving fewer than 100,000 customers spent less than $\$ 10,000$ annually on marketing (excluding staff time), with the remaining utilities potentially spending as much as $\$ 50,000$. Of midsized utilities ranging from 100,000 to 499,999 customers, the majority spent $\$ 10,000$ to $\$ 50,000$, with just two utilities spending more than $\$ 250,000$, and about one-third spending less than $\$ 10,000$. Of the large utilities with more than 500,000 customers, there was a wider range of marketing expenditures reported. One-third of large utilities spent less than $\$ 50,000$ on marketing, while about half spent more than $\$ 100,000$. The top performers ${ }^{16}$ represent a higher percentage of the higher marketing expenditures (Table 23).

With respect to program-administration spending, the data reflect the same general trends as with marketing expenditures (Table 24). Of the small utilities serving fewer than 100,000 customers, about $90 \%$ spent less than $\$ 10,000$ on administration (including staff time), with the remainder spending up to $\$ 100,000$. Of the midsized utilities ranging from 100,000 to 499,999 customers, most spent $\$ 10,000$ to $\$ 50,000$ on program administration, with about $10 \%$ spending more than $\$ 100,000$. The largest utilities serving more than 500,000 customers reported a wide range of expenditures on administration, similar to the marketing data. More than half of the large utilities spent more than $\$ 100,000$ on administration, while about a third spent less than $\$ 50,000$.

\footnotetext{
${ }^{14}$ The utilities include: Continental Cooperative Services/Soyland, Midstate Electric Cooperative, North Carolina utilities participating in NC Green Power Program, PacifiCorp, Portland General Electric, Puget Sound Energy, Salt River Project, We Energies, and Wisconsin Public Power Inc.

${ }^{15}$ The utilities include: Austin Energy, Alliant Energy, Clallum County PUD, Edmond Electric, Eugene Water and Electric Board, Green Mountain Power, Holy Cross Energy, Madison Gas \& Electric, OG\&E Electric Services, We Energies, and Xcel Energy.

${ }^{16}$ The top performers are defined as those that were among the top 10 programs for customer participants, green power sales, and customer participation rate, according to the NREL rankings (see Appendix C).
} 
Table 23: Utility Expenditures on Marketing in 2005 (Excluding Staff Time)

\begin{tabular}{|c|c|c|c|c|c|c|}
\hline \multirow{2}{*}{$\begin{array}{l}\text { Number of Utility } \\
\text { Customers }\end{array}$} & \multicolumn{5}{|c|}{ Number of Responses } & \multirow{2}{*}{$\begin{array}{c}\text { Total } \\
\text { Responses }\end{array}$} \\
\hline & $\begin{array}{c}\text { Less than } \\
\$ 10,000\end{array}$ & $\begin{array}{l}\$ 10,000- \\
\$ 50,000\end{array}$ & $\begin{array}{l}\$ 50,000- \\
\$ 100,000\end{array}$ & $\begin{array}{l}\$ 100,000- \\
\$ 250,000\end{array}$ & $\begin{array}{l}\$ 250,000- \\
\$ 500,000\end{array}$ & \\
\hline $1-99,999$ & 35 & 6 & 0 & 0 & 0 & 41 \\
\hline $100,000-499,999$ & 7 & 13 & 0 & 0 & 2 & 22 \\
\hline $500,000-999,999$ & 2 & 1 & 2 & 2 & 2 & 9 \\
\hline $1,000,000+$ & 2 & 1 & 0 & 4 & 2 & 9 \\
\hline Total Respondents & 46 & 21 & 2 & 6 & 6 & 81 \\
\hline $\begin{array}{r}\text { Top Performers/ } \\
\% \text { All Respondents }\end{array}$ & $2 / 4 \%$ & $3 / 14 \%$ & $1 / 50 \%$ & $4 / 67 \%$ & $3 / 50 \%$ & $13 / 16 \%$ \\
\hline
\end{tabular}

Table 24: Utility Expenditures on Program Administration in 2005 (Including Staff Time)

\begin{tabular}{|r|c|c|c|c|c|c|c|}
\hline \multirow{2}{*}{$\begin{array}{c}\text { Number of Utility } \\
\text { Customers }\end{array}$} & $\begin{array}{c}\text { Less } \\
\text { than } \\
\mathbf{\$ 1 0 , 0 0 0}\end{array}$ & $\begin{array}{c}\mathbf{\$ 1 0 , 0 0 0 -} \\
\mathbf{\$ 4 9 , 9 9 9}\end{array}$ & $\begin{array}{c}\mathbf{\$ 5 0 , 0 0 0 -} \\
\mathbf{\$ 9 9 , 9 9 9}\end{array}$ & $\begin{array}{c}\mathbf{\$ 1 0 0 , 0 0 0}- \\
\mathbf{\$ 2 4 9 , 0 0 0}\end{array}$ & $\begin{array}{c}\mathbf{\$ 2 5 0 , 0 0 0 -} \\
\mathbf{\$ 4 9 9 , 9 9 9}\end{array}$ & $\begin{array}{c}\mathbf{\$ 5 0 0 , 0 0 0 -} \\
\mathbf{\$ 7 5 0 , 0 0 0}\end{array}$ & Total \\
\hline $1-99,999$ & 36 & 4 & 1 & 0 & 0 & 0 & 41 \\
\hline $100,000-499,999$ & 3 & 10 & 4 & 2 & 0 & 0 & 19 \\
\hline $500,000-999,999$ & 3 & 2 & 2 & 1 & 0 & 1 & 9 \\
\hline $1,000,000+$ & 2 & 1 & 1 & 5 & 1 & 0 & 10 \\
\hline $\begin{array}{r}\text { Total } \\
\text { Respondents }\end{array}$ & 44 & 17 & 8 & 8 & 1 & 1 & 79 \\
\hline $\begin{array}{r}\text { Top Performers/ } \\
\% \text { Total }\end{array}$ & $3 / 7 \%$ & $3 / 18 \%$ & $1 / 13 \%$ & $5 / 63 \%$ & $0 / 0 \%$ & $1 / 100 \%$ & $13 / 16 \%$ \\
\hline $\begin{array}{r}\text { Respondents }\end{array}$ & & & & & & & \\
\hline
\end{tabular}

In 2005, utilities reported that a median of $2 \%$ (average of $15 \%$ ) of the total green power premium was spent on marketing and program administration (Table 25), ${ }^{17}$ while the topperforming programs reported spending a median of $23 \%$ and an average of $29 \%$. A number of utilities, primarily public utilities and cooperatives, reported that no portion of the premium was used for marketing and administration. For some utilities, this is because they use overall utility marketing dollars to advertise the program and do not include these costs in the program premium, whereas others are not actively promoting their programs. The decline in the fraction of the premium attributed to marketing costs may reflect a slowdown in marketing activities by some utilities.

\footnotetext{
${ }^{17}$ In 2002 , utilities reported spending a median of $15 \%$ (average of $20 \%$ ) of their program budgets on marketing. It is not possible to compare responses for 2002 and 2003/2004, because the questions differed.
} 
Table 25: Marketing and Administrative Expenditures as Percentage of Premium, 2005

\begin{tabular}{|c|c|c|c|}
\hline & $\mathbf{2 0 0 3}$ & $\mathbf{2 0 0 4}$ & $\mathbf{2 0 0 5}$ \\
\hline Average & $17 \%$ & $20 \%$ & $15 \%$ \\
\hline Median & $5 \%$ & $9 \%$ & $2 \%$ \\
\hline No. of Responses & 36 & 60 & 59 \\
\hline
\end{tabular}

Thirty-eight programs (54\%) indicated that program participants cover all costs associated with the green pricing program. Of the remaining 32 programs in which nonparticipants cover some costs, most program managers explained that some marketing and administrative costs were not attributed to the program (i.e., spread among all ratepayers). The other most commonly cited reasons were that the green pricing program received grants or other contributions, and that the utility spread the cost of unsold renewable energy among all ratepayers (Table 26). Results were similar in 2003 and 2004.

Table 26: Explanation of Costs Born by Nonparticipants, 2005

\begin{tabular}{|l|c|}
\hline & $\begin{array}{c}\text { Number of } \\
\text { Responses }\end{array}$ \\
\hline $\begin{array}{l}\text { Some marketing and administrative costs shared by all ratepayers (or } \\
\text { not attributed to the green pricing program) }\end{array}$ & 23 \\
\hline $\begin{array}{l}\text { The program receives grants, public goods funds, subsidies, or other } \\
\text { contributions }\end{array}$ & 3 \\
\hline $\begin{array}{l}\text { The utility spreads the cost of unsold renewable energy among all } \\
\text { ratepayers }\end{array}$ & 1 \\
\hline $\begin{array}{l}70 \text { programs responded, and } 33 \text { programs provided explanations; not all explanations are accounted for in } \\
\text { this table. }\end{array}$ \\
\hline
\end{tabular}

\section{Customer Acquisition}

One measure of the cost of marketing a green pricing program is customer-acquisition cost-the marketing expenditures divided by the number of new customers that enroll in the program. For 2005 , utilities providing data reported median and average residential customer-acquisition costs for green pricing programs of $\$ 25$ and $\$ 43$, respectively (Table 27). ${ }^{18}$ However, the responses varied widely, ranging from $\$ 0$ to more than $\$ 300$ (Figure 2). The top-performing programs reported median and average residential customer-acquisition costs of $\$ 27$ and $\$ 31$, respectively.

\footnotetext{
${ }^{18}$ Only about half of the utilities provided this information. The relative lack of responses may be resultant of some utilities not tracking customer-acquisition costs.
} 
Table 27: Residential Customer-Acquisition Costs by Year

\begin{tabular}{|l|c|c|c|c|c|c|}
\hline & $\mathbf{2 0 0 2}$ & $\mathbf{2 0 0 3}$ & $\mathbf{2 0 0 4}$ & $\mathbf{2 0 0 5}$ & $\begin{array}{c}\text { 2004 Top } \\
\text { Performers }\end{array}$ & $\begin{array}{c}\text { 2005 Top } \\
\text { Performers }\end{array}$ \\
\hline Average & $\$ 44$ & $\$ 36$ & $\$ 42$ & $\$ 43$ & $\$ 48$ & $\$ 31$ \\
\hline Median & $\$ 30$ & $\$ 31$ & $\$ 30$ & $\$ 25$ & $\$ 40$ & $\$ 27$ \\
\hline No. of Respondents & 25 & 22 & 43 & 45 & 18 & 10 \\
\hline
\end{tabular}

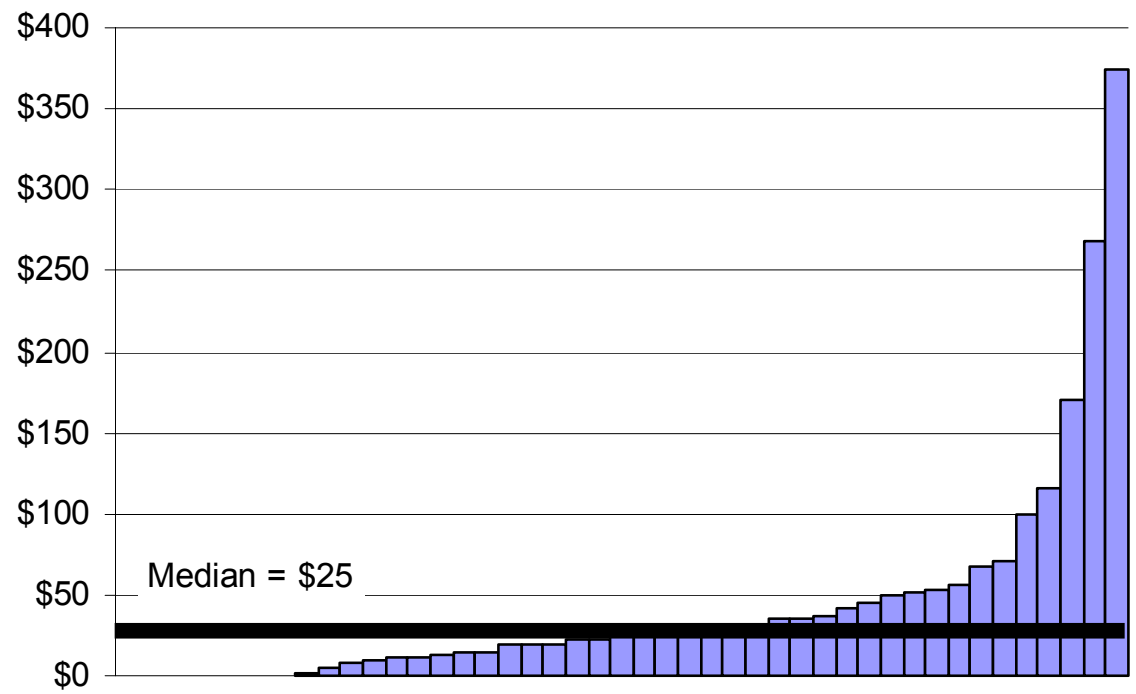

Figure 2: Customer-Acquisition Costs, 2005

Table 28: Residential Customer-Acquisition Costs by Utility Size

\begin{tabular}{|c|c|c|c|c|c|c|c|c|c|}
\hline \multirow{2}{*}{$\begin{array}{l}\text { Size of } \\
\text { Utility }\end{array}$} & \multicolumn{3}{|c|}{2003} & \multicolumn{3}{|c|}{2004} & \multicolumn{3}{|c|}{2005} \\
\hline & Avg. & Median & $\begin{array}{c}\text { No. } \\
\text { Resp. }\end{array}$ & Avg. & Median & $\begin{array}{l}\text { Num. } \\
\text { Resp. }\end{array}$ & Avg. & Median & $\begin{array}{c}\text { No. } \\
\text { Resp. }\end{array}$ \\
\hline $\begin{array}{r}1-99,999 \\
\text { Customers }\end{array}$ & $\$ 10$ & $\$ 5$ & 7 & $\$ 12$ & $\$ 4$ & 12 & $\$ 27$ & $\$ 14$ & 21 \\
\hline $\begin{array}{r}100,000- \\
499,999 \\
\text { Customers }\end{array}$ & $\$ 46$ & $\$ 40$ & 7 & $\$ 56$ & $\$ 35$ & 13 & $\$ 97$ & $\$ 41$ & 9 \\
\hline $\begin{array}{r}500,000- \\
999,999 \\
\text { Customers }\end{array}$ & $\$ 44$ & $\$ 38$ & 4 & $\$ 60$ & $\$ 55$ & 9 & $\$ 40$ & $\$ 28$ & 7 \\
\hline $\begin{array}{r}1,000,000 \\
\text { Customers }\end{array}$ & $\$ 57$ & $\$ 46$ & 4 & $\$ 41$ & $\$ 36$ & 9 & $\$ 29$ & $\$ 30$ & 8 \\
\hline $\begin{array}{r}\text { All } \\
\text { Utilities }\end{array}$ & $\$ 36$ & $\$ 31$ & 22 & $\$ 42$ & $\$ 30$ & 43 & $\$ 43$ & $\$ 25$ & 45 \\
\hline
\end{tabular}

Customer-acquisition costs differed considerably depending on the size of the utility (Table 28), with utilities serving more than 100,000 customers reporting higher customer-acquisition costs than smaller utilities. Some of the variability may be due to the types of costs that the utilities 
included in the calculation. For example, some utilities do not attribute all of the costs of marketing and administration to the program, which would lead to lower per-customer costs. Also, large utilities may have the resources to track expenditures more closely. And small utilities tend to rely on bill inserts and are less creative in targeted marketing.

\section{Marketing Techniques Employed}

The 2005 questionnaire asked respondents to indicate the various marketing techniques applied to their green pricing programs (Table 29). As in previous years, advertising programs through utility newsletters, bill inserts, events, news articles (publicity), and Web marketing were among the top marketing strategies used. ${ }^{19,20}$ A smaller fraction of utilities reported using television and partnering with environmental organizations.

In 2004 and 2005, utilities were also asked to rank the effectiveness of the various marketing techniques listed in the questionnaire. Marketing techniques that received average rankings above 3 out of a possible 5 included: bangtails, community challenges, bill inserts, door-to-door marketing, direct sales (to commercial accounts), direct mail, and publicity. Interestingly, the techniques with the highest effectiveness ranking were not necessarily the most commonly used. In 2005, programs employed an average of five of the marketing strategies listed in the questionnaire, while the top performers reported an average of eight. About a third of utilities reported using three or fewer marketing techniques (Table 30).

\footnotetext{
${ }^{19}$ In 2003, the "events" category was not listed as a specific option in the survey, but was listed under the "other" category by some respondents. The 2002 and 2004 surveys both included "events" as a category, and can therefore be compared with each other.

${ }^{20}$ Lieberman (2002) reviewed marketing data for public utilities with similar findings, except that direct mail was ranked higher.
} 
Table 29: Marketing Techniques Used by Utilities

\begin{tabular}{|c|c|c|c|c|c|c|c|c|c|c|c|}
\hline & \multicolumn{4}{|c|}{$\begin{array}{c}\text { Percent of Utilities Using } \\
\text { Technique }\end{array}$} & \multicolumn{3}{|c|}{$\begin{array}{c}\text { Percent Top } \\
\text { Performers Using } \\
\text { Technique }\end{array}$} & \multicolumn{4}{|c|}{$\begin{array}{c}\begin{array}{c}\text { Average Usefulness } \\
\text { Rank }^{\wedge}\end{array} \\
\end{array}$} \\
\hline & \multirow[b]{2}{*}{2002} & \multirow[b]{2}{*}{2003} & \multirow[b]{2}{*}{2004} & \multirow[b]{2}{*}{2005} & \multirow[b]{2}{*}{2003} & \multirow[b]{2}{*}{2004} & \multirow[b]{2}{*}{2005} & \multicolumn{2}{|c|}{2004} & \multicolumn{2}{|c|}{2005} \\
\hline & & & & & & & & All & Top & All & Top \\
\hline $\begin{array}{l}\text { Utility } \\
\text { newsletter }\end{array}$ & $70 \%$ & $81 \%$ & $78 \%$ & $74 \%$ & $87 \%$ & $73 \%$ & $81 \%$ & 2.9 & 2.9 & 2.9 & 2.8 \\
\hline Bill inserts & $61 \%$ & $83 \%$ & $74 \%$ & $66 \%$ & $87 \%$ & $73 \%$ & $75 \%$ & 3.2 & 3.4 & 3.5 & 3.7 \\
\hline Events & $80 \%$ & $24 \%{ }^{*}$ & $74 \%$ & $60 \%$ & $40 \%$ & $73 \%$ & $81 \%$ & 2.6 & 2.7 & 2.5 & 2.5 \\
\hline Publicity & $63 \%$ & $64 \%$ & $56 \%$ & $57 \%$ & $67 \%$ & $69 \%$ & $63 \%$ & 3.4 & 3.1 & 3.1 & 3.1 \\
\hline $\begin{array}{l}\text { Web } \\
\text { marketing^ }\end{array}$ & $\mathrm{n} / \mathrm{a}$ & $\mathrm{n} / \mathrm{a}$ & $56 \%$ & $54 \%$ & $\mathrm{n} / \mathrm{a}$ & $73 \%$ & $63 \%$ & 3.3 & 3.4 & 2.7 & 3.2 \\
\hline $\begin{array}{l}\text { Newspaper } \\
\text { ads }\end{array}$ & $43 \%$ & $53 \%$ & $36 \%$ & $42 \%$ & $60 \%$ & $46 \%$ & $50 \%$ & 2.5 & 2.1 & 2.2 & 2.4 \\
\hline Direct sales^ & $\mathrm{n} / \mathrm{a}$ & $\mathrm{n} / \mathrm{a}$ & $38 \%$ & $36 \%$ & $\mathrm{n} / \mathrm{a}$ & $50 \%$ & $63 \%$ & 3.5 & 3.8 & 3.4 & 3.5 \\
\hline Direct mail & $55 \%$ & $48 \%$ & $35 \%$ & $34 \%$ & $67 \%$ & $62 \%$ & $63 \%$ & 3.7 & 3.7 & 3.2 & 3.7 \\
\hline Radio ads & $37 \%$ & $45 \%$ & $22 \%$ & $27 \%$ & $53 \%$ & $19 \%$ & $25 \%$ & 2.5 & 1.2 & 2.4 & 2.3 \\
\hline Bangtails & $\mathrm{n} / \mathrm{a}$ & $\mathrm{n} / \mathrm{a}$ & $\mathrm{n} / \mathrm{a}$ & $16 \%$ & $\mathrm{n} / \mathrm{a}$ & $\mathrm{n} / \mathrm{a}$ & $38 \%$ & $\mathrm{n} / \mathrm{a}$ & $\mathrm{n} / \mathrm{a}$ & 3.9 & 4.5 \\
\hline $\begin{array}{l}\text { Partner with } \\
\text { environmental } \\
\text { groups }{ }^{\wedge \wedge}\end{array}$ & $\mathrm{n} / \mathrm{a}$ & $\mathrm{n} / \mathrm{a}$ & $26 \%$ & $16 \%$ & $\mathrm{n} / \mathrm{a}$ & $54 \%$ & $38 \%$ & 2.7 & 2.8 & 2.9 & 2.7 \\
\hline $\begin{array}{l}\text { Retail } \\
\text { partners^}\end{array}$ & $\mathrm{n} / \mathrm{a}$ & $\mathrm{n} / \mathrm{a}$ & $11 \%$ & $13 \%$ & $\mathrm{n} / \mathrm{a}$ & $23 \%$ & $31 \%$ & 2.9 & 3.0 & 2.5 & 2.2 \\
\hline Television ads & $20 \%$ & $22 \%$ & $15 \%$ & $10 \%$ & $13 \%$ & $31 \%$ & $31 \%$ & 2.3 & 1.8 & 1.5 & 1.8 \\
\hline Billboards & $7 \%$ & $7 \%$ & $8 \%$ & $7 \%$ & $7 \%$ & $12 \%$ & $13 \%$ & 3.2 & 2.0 & 1.7 & 1.5 \\
\hline $\begin{array}{l}\text { Community } \\
\text { challenges }^{\wedge}\end{array}$ & $\mathrm{n} / \mathrm{a}$ & $\mathrm{n} / \mathrm{a}$ & $7 \%$ & $5 \%$ & $\mathrm{n} / \mathrm{a}$ & $19 \%$ & $13 \%$ & 2.5 & 2.4 & 3.8 & 3.5 \\
\hline Kiosks^ $^{\wedge}$ & $\mathrm{n} / \mathrm{a}$ & $\mathrm{n} / \mathrm{a}$ & $7 \%$ & $5 \%$ & $\mathrm{n} / \mathrm{a}$ & $4 \%$ & 0 & 3.2 & 2.0 & 1.1 & 0 \\
\hline Other & $32 \%$ & $41 \%$ & $19 \%$ & $5 \%$ & $60 \%$ & $46 \%$ & $6 \%$ & 3.9 & 4.1 & 1.8 & 2.7 \\
\hline Telemarketing & $8 \%$ & $14 \%$ & $6 \%$ & $4 \%$ & $20 \%$ & $12 \%$ & $19 \%$ & 3.2 & 4.3 & 2.8 & 3.7 \\
\hline $\begin{array}{l}\text { Door -to- } \\
\text { door }\end{array}$ & $\mathrm{n} / \mathrm{a}$ & $\mathrm{n} / \mathrm{a}$ & $\mathrm{n} / \mathrm{a}$ & $2 \%$ & $\mathrm{n} / \mathrm{a}$ & $\mathrm{n} / \mathrm{a}$ & $6 \%$ & $\mathrm{n} / \mathrm{a}$ & $\mathrm{n} / \mathrm{a}$ & 3.3 & 5 \\
\hline $\begin{array}{l}\text { *Note: "Events" was } \\
\text { write it in under "Ot } \\
{ }^{* \star} \text { Top performers a } \\
26 \text { and } 16 \text { top prog } \\
\wedge \text { Ranking system is } \\
\wedge \wedge \text { New category in } \\
\wedge \wedge \wedge \text { New category in } \\
60 \text { programs provid }\end{array}$ & $\begin{array}{l}\text { resp } \\
\text { with } \\
5\end{array}$ & $\begin{array}{l}\text { tilities } \\
\text { d to th } \\
\text { ng the }\end{array}$ & $\begin{array}{l}\text { uesti } \\
\text { st us }\end{array}$ & $\begin{array}{l}\text { Iop } 1 \\
\text { specti } \\
\text { narket }\end{array}$ & echn & Ran & yster & 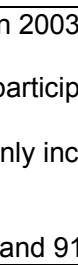 & ed in rat & 4. & $\begin{array}{l}\text { le to } \\
2005\end{array}$ \\
\hline
\end{tabular}


Compared to all programs, the top performers more commonly used many of the techniques listed, including direct mail, direct sales, partnerships with environmental organizations, bangtails, television ads, retail partnerships, and telemarketing. One potential reason for differences in marketing strategies used by top performers may be related to the marketing budgets. The top performers represent a significant majority of the programs that spend the most on marketing (see Table 23).

Table 30: Number of Marketing Techniques Used by Utilities

\begin{tabular}{|c|c|c|c|}
\hline $\begin{array}{c}\text { Number of } \\
\text { Techniques Used by } \\
\text { Utilities }\end{array}$ & $\mathbf{2 0 0 3}$ & $\mathbf{2 0 0 4}$ & $\mathbf{2 0 0 5}$ \\
\hline $0-1$ & $7 \%$ & $6 \%$ & $13 \%$ \\
\hline $2-3$ & $26 \%$ & $20 \%$ & $20 \%$ \\
\hline $4-6$ & $45 \%$ & $34 \%$ & $33 \%$ \\
\hline $7-9$ & $21 \%$ & $22 \%$ & $22 \%$ \\
\hline $10-13$ & n/a & $18 \%$ & $12 \%$ \\
\hline \multicolumn{2}{|c|}{$\begin{array}{c}\text { Note: There were } 58 \text { responses to this question in 2003, 88 in 2004, } \\
\text { and 91 in 2005. Percentages may not add to 100\% due to rounding. }\end{array}$} \\
\hline
\end{tabular}

\section{Program Implementation}

\section{Enrollment Options}

Utilities reported that the most common methods for enrolling customers in green pricing programs included using the utility's Web site, phoning through the utility's call center, returning mail-in cards, and signing up during special events (Table 31). Web site enrollment options have become more common since 2002, perhaps because utilities have improved their Web sites or increased their Web presence.

Table 31: Methods of Enrolling in Green Pricing Programs

\begin{tabular}{|c|c|c|c|c|c|c|}
\hline & \multicolumn{4}{|c|}{$\%$ Using Method } & \multirow{2}{*}{$\begin{array}{c}2005 \text { Top } \\
\text { Performers } \\
\text { \% Using } \\
\text { Method }\end{array}$} & \multirow{2}{*}{$\begin{array}{c}\text { Average } \\
\text { Rank } \\
1 \text { to } 5 \text {, } \\
5=\text { highest }\end{array}$} \\
\hline & 2002 & 2003 & 2004 & 2005 & & \\
\hline Utility Web site & $74 \%$ & $83 \%$ & $80 \%$ & $85 \%$ & $94 \%$ & 2.5 \\
\hline $\begin{array}{l}\text { Phone (utility } \\
\text { call center) }\end{array}$ & $92 \%$ & $87 \%$ & $84 \%$ & $84 \%$ & $94 \%$ & 2.8 \\
\hline $\begin{array}{l}\text { Returning } \\
\text { mail-in card }\end{array}$ & $90 \%$ & $85 \%$ & $83 \%$ & $81 \%$ & $100 \%$ & 3.9 \\
\hline $\begin{array}{l}\text { Enroll at } \\
\text { special events }\end{array}$ & $90 \%$ & $85 \%$ & $73 \%$ & $75 \%$ & $75 \%$ & 2.1 \\
\hline Other & $23 \%$ & $31 \%$ & $48 \%$ & $24 \%$ & $38 \%$ & 3.3 \\
\hline $\begin{array}{l}\text { Check-box on } \\
\text { utility bill }\end{array}$ & $8 \%$ & $12 \%$ & $15 \%$ & $13 \%$ & $13 \%$ & 3.1 \\
\hline
\end{tabular}


Only about $13 \%$ of utilities allowed customers to enroll by checking a box on their utility bills, but those that did ranked it high in effectiveness. Other methods that were ranked as relatively effective, with scores greater than 3 out of 5, included "other" methods (which respondents were asked to list) and mail-in cards. Some of the enrollment options listed under "other" included bill inserts, direct sales through account representatives (both residential and commercial), phone marketing by a contractor, and enrolling customers through retail partners or at the utility itself. On average, utilities offered three of the six enrollment options listed in the questionnaire. The top-performing programs were more likely to use most of the techniques listed.

\section{Enrollment Term}

Roughly one-quarter to one-third of utilities require residential and nonresidential customers to subscribe to green pricing programs for a minimum period of time (Table 32). One year is the most common minimum enrollment period, with requirements ranging from 2 months to 10 years. In some cases, utilities require nonresidential customers to enroll for longer periods of time than residential customers. Only four residential and six nonresidential programs had enrollment terms of more than one year in length.

Table 32: Enrollment Term by Customer Segment

\begin{tabular}{|l|c|c|}
\hline & Residential & Nonresidential \\
\hline Percent of utilities with a minimum enrollment term & $26 \%$ & $32 \%$ \\
\hline Most common enrollment term & 1 year & 1 year \\
\hline Range of enrollment requirements & $\begin{array}{c}2 \text { months to } 10 \\
\text { years }\end{array}$ & $\begin{array}{c}2 \text { months to } 10 \\
\text { years }\end{array}$ \\
\hline$* 81$ residential and 77 nonresidential programs responded to this question. \\
\hline
\end{tabular}

\section{Program Evaluations and Market Research}

Fifty-three utilities (58\%) reported that they had conducted customer research to aid the design of their green pricing program or to develop a marketing plan. Of the 53 utilities, eight did so in 2005 and 27 did so in multiple years including 2005. The types of research ranged from consumer surveys conducted by phone, mail, in person (focus groups), or the Web (25 utilities reported); customer profiling and demographics (3); research to test the effectiveness of marketing messages or strategies (3); and research to determine customer satisfaction (1). Of the responding top-performing programs (16), 100\% reported conducting market research.

In terms of program evaluation, 29 respondents (32\%) indicated that they had performed a program evaluation in 2005 or earlier. Fourteen of the programs reported evaluating their programs continually, annually, or biannually. Utilities listed that they evaluated factors such as: 
messaging, market channel effectiveness, advertising effectiveness, campaign effectiveness, and acquisition costs, as well as program participation or success in meeting program goals. Of the top-performing programs, $59 \%$ reported conducting one or more program evaluation, compared to $32 \%$ of all programs.

\section{Customer Value}

Response to utility green pricing programs can be influenced by additional values offered to both residential and nonresidential customers (Wiser et al. 2004). For example, customers may be more willing to participate in a program if their participation is recognized or rewarded, or if they receive other products and services, such as compact fluorescent lightbulbs or store discounts.

Table 33 indicates the percentage of utilities that provide additional benefits to customers, based on a list of options included in the 2002-2005 questionnaires. Of the 11 options listed, respondents indicated that their utilities offered an average of three additional benefits to their green pricing customers. As in previous years, the most common added benefits in 2005 were 1) to inform customers about the status of the program through newsletters that provide periodic program updates, 2) to provide decals that can be displayed in windows, 3) to recognize participants with plaques or other items, and 4) to recognize business customers through ads in local media. The fraction of utilities offering 1) tours to renewable energy facilities and 2) installing renewable energy systems on schools or offering renewable energy education programs have trended downward during the past recorded years. A relatively small fraction of utilities offer compact fluorescent lightbulbs or energy efficiency products, discounts or promotions at local businesses, protection from fuel cost increases, or exemption from environmental fees (e.g., fees designated for installing emission-control equipment at fossil fuel plants).

As in previous years, the top-performing programs were more likely to offer many of the benefits listed in Table 33. For example, 69\% of the top performers recognized business participants through ads in local media or with plaques or other items, compared to about $46 \%$ of all programs. The top performers were also more likely to provide decals for display in store windows, discounts, or promotions at local businesses; to protect customers from fuel cost increases; and provide energy efficiency products. Overall, top performers reported providing an average of six of the benefits listed, compared to an average of three for all programs. 
Table 33: Methods of Providing Additional Program Benefits

\begin{tabular}{|c|c|c|c|c|c|}
\hline & & $\%$ Usin & Method & & Top Performers \\
\hline & 2002 & 2003 & 2004 & 2005 & $\begin{array}{c}2005, \% \text { Using } \\
\text { Method }^{*}\end{array}$ \\
\hline $\begin{array}{l}\text { Newsletters that provide } \\
\text { program updates }\end{array}$ & $62 \%$ & $64 \%$ & $61 \%$ & $62 \%$ & $88 \%$ \\
\hline $\begin{array}{l}\text { Decals for display in store } \\
\text { windows }\end{array}$ & $59 \%$ & $56 \%$ & $49 \%$ & $54 \%$ & $81 \%$ \\
\hline $\begin{array}{l}\text { Recognition of business } \\
\text { customers in program ads or } \\
\text { local media }\end{array}$ & $44 \%$ & $51 \%$ & $49 \%$ & $46 \%$ & $69 \%$ \\
\hline $\begin{array}{l}\text { Plaques or other items for } \\
\text { recognition }\end{array}$ & $40 \%$ & $49 \%$ & $51 \%$ & $44 \%$ & $63 \%$ \\
\hline $\begin{array}{l}\text { Installations on } \\
\text { schools/renewable energy } \\
\text { education programs }\end{array}$ & $30 \%$ & $25 \%$ & $19 \%$ & $30 \%$ & $38 \%$ \\
\hline $\begin{array}{l}\text { Tours to renewable energy } \\
\text { project sites }\end{array}$ & $35 \%$ & $29 \%$ & $23 \%$ & $25 \%$ & $31 \%$ \\
\hline Other & $5 \%$ & $12 \%$ & $16 \%$ & $16 \%$ & $6 \%$ \\
\hline $\begin{array}{l}\text { Compact fluorescents or } \\
\text { efficiency products }\end{array}$ & $22 \%$ & $12 \%$ & $15 \%$ & $15 \%$ & $25 \%$ \\
\hline $\begin{array}{l}\text { Discounts or promotions at } \\
\text { local businesses }\end{array}$ & $8 \%$ & $12 \%$ & $12 \%$ & $15 \%$ & $44 \%$ \\
\hline $\begin{array}{l}\text { Protection from fuel-cost } \\
\text { increases }\end{array}$ & $11 \%$ & $10 \%$ & $9 \%$ & $15 \%$ & $44 \%$ \\
\hline $\begin{array}{l}\text { Exemption from } \\
\text { environmental fees }\end{array}$ & $2 \%$ & $2 \%$ & $1 \%$ & $2 \%$ & $12 \%$ \\
\hline
\end{tabular}




\section{Conclusions and Observations}

At the end of 2005, more than 600 utilities - including many small municipal and cooperative utilities - offered green pricing programs to more than 50 million customers nationally. About $20 \%$ of all utilities nationwide now offer a green pricing option.

Collectively, utilities sold nearly 3 billion kilowatt-hours $(\mathrm{kWh})$ of green power to more than 450,000 customers in 2005. In traditionally regulated electricity markets, sales of renewable energy through utility green pricing programs grew by $33 \%$ to about 2.5 billion $\mathrm{kWh}$ in 2005 , following annual growth in excess of $40 \%$ in 2003 and 2004. The increase resulted from both an increase in customer participants as well as larger purchases by nonresidential customers. However, green pricing sales still represent a very small fraction of total utility electricity sales, with an average below $1 \%$ - although some utilities have achieved sales penetration rates of as much as $4 \%$.

For utility/marketer programs offered in restructured electricity markets, the number of customers and renewable energy sales more than doubled during 2005. These high growth rates may be explained, in part, by the relative infancy of most competitive market programs and the fact that these programs are implemented in conjunction with companies that specialize in renewable energy marketing, which have a vested financial interest in program success.

The number of customers participating in utility green pricing programs increased by about $20 \%$ in 2005, a slower pace than sales. The number of nonresidential participants increased at nearly twice the rate of residential customers, in contrast to 2004 when growth rates were similar. Programs that offer fuel price-protection benefits or those that offer volume discounts or lower premiums for large nonresidential purchasers contributed significantly to growth in nonresidential participants during 2005, suggesting that these are important program benefits for nonresidential consumers.

Customer attrition rates fell to a median of 5\% in 2005, reversing a recent trend of increasing dropout rates. This finding is somewhat surprising in a year in which customers throughout the country faced higher electricity and energy prices. Although the reason for the overall improvement in customer retention is not clear, it suggests that green power customers are "sticky" and tend to maintain participation in green power programs, despite cost increases.

As in previous years, a relatively small number of utility green power programs continue to dominate sales and participation figures. The top 10 programs accounted for about $70 \%$ of green energy sales and $65 \%$ of customer participants, consistent with figures from 2004. As in the past, one utility program (Austin Energy) accounted for nearly $20 \%$ of all green pricing sales. This utility offers a fixed-price product that protects participating customers from nonrenewable fuelcost increases for up to 10 years. This value-added strategy has proven to be extremely popular among nonresidential customers.

Average participation rates in green pricing programs have remained relatively flat over time, climbing slightly to $1.5 \%$ in 2005 . Participation rates among the 10 most successful programs have been substantially higher, ranging from between about 5\% and 14\% in 2005 with most 
clustered from $5 \%$ to $6 \%$. This suggests that high participation rates are possible with dedicated marketing and outreach campaigns, or in programs that offer superior value propositions. However, these rates still remain well below the $50 \%$ to $70 \%$ of customers who indicate they are willing to pay a premium for green power in market research surveys (Farhar 1999).

The price premiums charged for green power continued on a downward trend. The average premium has fallen from $2.93 \phi / \mathrm{kWh}$ in 2001 to $2.36 \notin / \mathrm{kWh}$ in 2005 ; the median premium remained constant at $2 \phi / \mathrm{kWh}$. Several programs that exempt participants from fossil fuel cost changes offered green power at rates below standard electricity prices during 2005. In addition, a number of programs were able to reduce the price premium because of fossil fuel-charge exemptions or by renegotiating power purchase contracts at lower rates. Also, several utilities introduced programs that offer volume discounts or lower premiums for large, nonresidential purchasers.

Utilities reported a median cost of $\$ 25$ for acquiring new residential customers, down from the approximately $\$ 30$ reported in previous years. Marketing expenditures generally vary with utility size, but there is wide variation in expenditures among the largest utilities. On average, the topperforming programs spend a greater portion of program revenues on marketing and represent most of the top marketing spenders. Thus, the level of marketing expenditures appears to be important to program success.

The top performers generally use a larger number of marketing techniques than other utilities. Compared to all programs, the top performers more commonly used direct mail, direct sales, partnerships with environmental organizations, bangtails, television ads, retail partnerships, and telemarketing. Consistent with findings from previous years, the techniques that received high effectiveness scores are not necessarily the most commonly used. In general, utilities may benefit from diversifying their marketing activities to include some of the more effective strategies.

At the end of 2005, green pricing programs were supporting the equivalent of more than 740 MW of new renewable energy capacity. Thus, green pricing continues to be a viable strategy for supporting new renewable energy sources. Nevertheless, current success can still be attributed to a relatively small number of programs. Continued industry growth will depend largely on the introduction of new programs and whether the success of the top-performing programs can be duplicated by other utilities. 


\section{References}

Bird, L. and E. Brown, 2005. Trends in Utility Green Pricing Programs (2004). Golden, CO: National Renewable Energy Laboratory, NREL/TP-620-38800. October. http://www.eere.energy.gov/greenpower/resources/pdfs/38800.pdf

Bird, L. and K. Cardinal, 2004. Trends in Utility Green Pricing Programs (2003). Golden, CO: National Renewable Energy Laboratory. NREL/TP-620-36833, September. http://www.eere.energy.gov/greenpower/pdfs/36833.pdf

Bird, L. and B. Swezey, 2005a. Green Power Marketing in the United States: A Status Report (Eighth Edition), NREL/TP-620-38994. Golden, CO: National Renewable Energy Laboratory, October. http://www.eere.energy.gov/greenpower/resources/pdfs/38994.pdf

Bird, L. and B. Swezey, 2005b. Estimates of New Renewable Energy Capacity Serving U.S. Green Power Markets (2004). Golden, CO: National Renewable Energy Laboratory, May. http://www.eere.energy.gov/greenpower/resources/tables/new gp cap.shtml

Bird, L. and B. Swezey, 2004. Green Power Marketing in the United States: A Status Report (Seventh Edition), NREL/TP-620-36823. Golden, CO: National Renewable Energy Laboratory, September. http://www.eere.energy.gov/greenpower/pdfs/36823.pdf

Bird, L., B. Swezey, and J. Aabakken, 2004. Utility Green Pricing Programs: Design, Implementation, and Consumer Response. Report prepared by National Renewable Energy Laboratory, Golden Colorado, February. NREL/TP-620-35618. http://www.eere.energy.gov/greenpower/resources/pdfs/nrel 35618.pdf

Farhar, B., 1999. Willingness to Pay for Electricity from Renewable Resources: A Review of Utility Market Research, NREL/TP-550-26148. Golden, CO: National Renewable Energy Laboratory, July. http://www.eere.energy.gov/greenpower/farhar_26148.html

Holt, E.A., and M. Holt, 2004. Green Pricing Resource Guide (2nd Edition), Ed Holt \& Associates, Inc., Harpswell, Maine. Prepared for the American Wind Energy Association, Washington DC, September. http://www.awea.org/greenpower/greenPricingResourceGuide040726.pdf

Lieberman, D., 2002. Green Pricing at Public Utilities: A How-To Guide Based on Lessons Learned to Date, Prepared for the Public Renewables Partnership by the Center for Resource Solutions, San Francisco, California, October.

Swezey, B. and L. Bird, 2001. Utility Green Pricing Programs: What Defines Success? NREL/TP-620-29831. Golden, CO: National Renewable Energy Laboratory, August. http://www.eere.energy.gov/greenpower/29831.pdf 
Swezey, B. and L. Bird, 2000. Green Power Marketing in the United States: A Status Report (Fifth Edition), NREL/TP-620-28738. Golden, CO: National Renewable Energy Laboratory, August. http://www.eere.energy.gov/greenpower/pdf/28738.pdf

Swezey, B. and L. Bird, 1999. Information Brief on Green Power Marketing (Fourth Edition), NREL/TP-620-26901. Golden, CO: National Renewable Energy Laboratory, August. http://www.nrel.gov/analysis/emaa/brief 4.html

Washington Department of Community, Trade and Economic Development (CTED) and Utilities Transportation Commission (UTC), 2005. Green Power Programs in Washington: 2005 Report to the Legislature. Olympia, WA, December. http://qa.cted.wa.gov/_CTED/documents/ID_2641_Publications.pdf

Wiser, R., S. Olson, L. Bird and B. Swezey, 2004. Utility Green Pricing Programs: A Statistical Analysis of Program Effectiveness, LBNL-54437. Berkeley, CA: Lawrence Berkeley National Laboratory, February. http://www.eere.energy.gov/greenpower/resources/pdfs/lbnl_54437.pdf 


\section{Appendix A \\ Utility Green Power Program Questionnaire (2005 Data)}

Instructions - Please fill out a different form for each green power program offered. Please enter data for calendar year 2005 .

Confidentiality - Individual utility responses to this survey regarding customers, sales, and marketing information will be held confidential. Data are used to prepare NREL's list of top ten utility green power programs and to provide aggregate industry data to the U.S. DOE and the general public.

1. Program and Contact Information

\begin{tabular}{|l|l|}
\hline a. Utility Name & \\
\hline b. Name of Green Power Program & \\
\hline c. Name of Respondent & \\
\hline d. Phone and e-mail of Respondent & \\
\hline e. Year Program Launched & \\
\hline f. States in which Program is Offered & \\
\hline g. Name of Third-party Marketer, if any & \\
\hline h. Certifying Organization, if Certified & \\
\hline
\end{tabular}

2. Participation. In the table below, please provide participation data as of December 31, 2005. If data are provided for a different time period, please indicate.

\begin{tabular}{|l|l|}
\hline a. Total number of residential green power participants & \\
\hline b. Total number of non-residential green power participants & \\
\hline c. Number of new residential green power participants in 2005 (do not subtract dropouts) & \\
\hline d. Number of new non-residential green power participants in 2005 (do not subtract dropouts) & \\
\hline e. Total number of residential customers (or members) eligible to participate & \\
\hline f. Total number of non-residential customers (or members) eligible to participate & \\
\hline g. Is the program currently open to new customers? Yes/No & \\
\hline h. Number of customers on waiting list & \\
\hline i. Number of participants who have dropped out of the program this year & \\
\hline j. Minimum period of time residential customers must participate (e.g., 1 year) & \\
\hline k. Minimum period of time non-residential customers must participate (e.g., 2 years) & \\
\hline
\end{tabular}

3. Programs Offered Through Distribution Utilities. For programs that are offered through multiple distribution cooperatives or municipal utilities, please list the number of distribution utilities that offer the program and utilities that have achieved participation rates of $4 \%$ or higher. Please add more space, if necessary.

\begin{tabular}{|l|l|l|}
\hline Number of Distribution Utilities That Offer Program & Utilities with $>\mathbf{4 \%}$ Participation & $\begin{array}{l}\text { Participation } \\
\text { Rate }\end{array}$ \\
\hline & & \\
\hline
\end{tabular}

4. Pricing. Please indicate the price premium as of the end of 2005.

\begin{tabular}{|l|l|l|l|l|l|}
\hline Sector & $\begin{array}{l}\text { Price } \\
\text { Premium } \\
\mathbf{(} / \mathbf{k W h})\end{array}$ & $\begin{array}{l}\text { Are Participants Exempt } \\
\text { from Fuel Charge? Y/N If } \\
\text { yes, what was fuel charge in } \\
\text { Dec 2005? } \mathbf{(} / \mathbf{k W h})\end{array}$ & $\begin{array}{l}\text { Change in } \\
\text { Premium in } \\
2005 ? \mathbf{Y} / \mathbf{N}^{*}\end{array}$ & $\begin{array}{l}\text { Block Size, if } \\
\text { applicable } \\
\mathbf{( k W h )}\end{array}$ & $\begin{array}{l}\text { Minimum } \\
\text { Purchase } \\
\mathbf{( e . g . ~ 2 5 \% ~ o r ~} \\
\mathbf{k W h})\end{array}$ \\
\hline & & & & \\
\hline a. Residential & & & & \\
\hline
\end{tabular}

5. Renewable Energy Sales for 2005. In the table below, please indicate the total annual sales of green power to customers during 2005. If sales are reported for a different period other than January through December 2005, please indicate. 


\begin{tabular}{|l|l|}
\hline Green power sales for 2005 & TOTAL 2005 Sales ( $k$ Wh $)$ \\
\hline a. Green power sales to residential customers & \\
\hline b. Green power sales to non-residential customers & \\
\hline c. Total retail electricity sales to eligible residential customers & \\
\hline d. Total retail electricity sales to eligible non-residential customers & \\
\hline
\end{tabular}

6. Renewable Energy Mandates. Does your utility count the green power sold to customers through your green pricing program toward compliance with a state-imposed renewable portfolio standard? Yes / No

7. Sales by Renewable Resource. In the table below, list the percentage of sales supplied by each of the following renewable resources in 2005. Also, please indicate the percentage of sales supplied by new renewable energy sources, if different.

\begin{tabular}{|l|c|c|}
\hline \multicolumn{1}{|c|}{ Resource } & $\begin{array}{c}\text { Percent of Sales Supplied } \\
\text { by Resource Type }\end{array}$ & $\begin{array}{c}\text { Percent of Sales Supplied } \\
\text { by New* Resources }\end{array}$ \\
\hline Biomass: Landfill Gas & $\%$ & $\%$ \\
\hline Biomass: Biogas & $\%$ & $\%$ \\
\hline Biomass: Wood or Other & $\%$ & $\%$ \\
\hline Geothermal & $\%$ & $\%$ \\
\hline Hydroelectric & $\%$ & $\%$ \\
\hline Solar & $\%$ & $\%$ \\
\hline Wind & $\%$ & $\%$ \\
\hline$* *$ New resources defined as those in service or repowered after January 1, 1997. \\
\hline
\end{tabular}

8. Renewable Energy Supplies. Of the renewable energy used to supply your program, what percentage came from the following?

\begin{tabular}{|l|c|}
\hline Renewable projects owned or partially-owned by your utility & $\%$ \\
\hline Renewable energy purchases from other suppliers/producers & $\%$ \\
\hline Renewable energy produced by utility customers (e.g. PV) & $\%$ \\
\hline Renewable certificate purchases & $\%$ \\
\hline Total & $100 \%$ \\
\hline
\end{tabular}

9. Renewable Energy Projects Supplying Program. In the table below, please indicate the type and amount of renewable resources used to supply participants in your green pricing program during 2005.

\begin{tabular}{|l|l|l|l|l|}
\hline $\begin{array}{l}\text { Name(s) of Renewable } \\
\text { Energy Project Used to } \\
\text { Supply Program }\end{array}$ & $\begin{array}{l}\text { Resource } \\
\text { Type (e.g.,. } \\
\text { Wind, PV) }\end{array}$ & $\begin{array}{l}\text { Nameplate } \\
\text { Capacity Installed (kW) }\end{array}$ & $\begin{array}{l}\text { Year } \\
\text { Installed }\end{array}$ & $\begin{array}{l}\text { 2005 Energy or REC } \\
\text { Purchases (kWh/yr) }\end{array}$ \\
\hline & & & & \\
\hline & & & & \\
\hline
\end{tabular}

10. Planned Renewable Energy Supplies. In the table below, please indicate any planned renewable energy projects that will be used to supply participants in your green pricing program.

\begin{tabular}{|l|l|l|l|}
\hline $\begin{array}{l}\text { Name(s) of Planned Renewable Energy } \\
\text { Projects to Supply Program in Future }\end{array}$ & $\begin{array}{l}\text { Resource Type } \\
\text { (e.g.,. Wind, PV) }\end{array}$ & $\begin{array}{l}\text { Nameplate Capacity } \\
\text { Planned (kW) }\end{array}$ & $\begin{array}{l}\text { Year } \\
\text { Planned }\end{array}$ \\
\hline & & & \\
\hline & & & \\
\hline
\end{tabular}

11. Program Research. Have you performed (in 2005 or earlier) market research to aid in the design of your green power program or have you performed a program evaluation?

\begin{tabular}{|l|c|c|c|}
\hline \multicolumn{1}{|c|}{ Research Category } & $\begin{array}{c}\text { Did you Perform? } \\
\text { Y/N }\end{array}$ & $\begin{array}{c}\text { In what year(s) was } \\
\text { research performed? }\end{array}$ & Type of Research or Evaluation Performed \\
\hline a. Market Research & & & \\
\hline b. Program Evaluation & & & \\
\hline
\end{tabular}


12. Customer Enrollment. In which ways can customers sign up for your program? (check all that apply) Also, please rate the effectiveness of each method on a scale of 1 to 5 , with 5 being the most effective.

\begin{tabular}{|l|l|l|}
\hline & $\begin{array}{l}\text { Check } \\
(\mathrm{x})\end{array}$ & $\begin{array}{l}\text { Effectiveness Rating } \\
(\mathbf{1 - 5} \text { scale, 5=most effective) }\end{array}$ \\
\hline Utility Web site & & \\
\hline By returning a mail-in card/bangtail & & \\
\hline Checking a box on their electric bill & & \\
\hline Sign up at special events & & \\
\hline By phone through the utility call center & & \\
\hline Other? (specify) & & \\
\hline
\end{tabular}

13: Value-Added Products. What other value-added products or services do you provide to customers that enroll in your green power program? (check all that apply)

\begin{tabular}{|l|l|l|l|}
\hline Compact fluorescents or efficiency products & & Decals for display in store windows & \\
\hline Recognition of business customers in program ads or local media & & Education programs/school installations & \\
\hline Discounts or promotions at local businesses & & Plaques, certificates or other recognition & \\
\hline Newsletters that provide program updates & & Protection from fuel cost increases & \\
\hline Tours to renewable energy project sites & & Exemption from environmental fees & \\
\hline Welcome Kit/Thank you letter & & Other (List): & \\
\hline
\end{tabular}

14. Marketing and Administration Spending. Please indicate below how much you spend annually on marketing and administration of your green power program. (check the appropriate boxes below)

\begin{tabular}{|l|c|c|}
\hline & $\begin{array}{c}\text { Marketing Costs } \\
\text { excluding staff time) }\end{array}$ & $\begin{array}{c}\text { Administrative Costs } \\
\text { (including staff time) }\end{array}$ \\
\hline Less than $\$ 10,000$ & & \\
\hline$\$ 10,000-\$ 49,999$ & & \\
\hline$\$ 50,000-\$ 99,999$ & & \\
\hline$\$ 100,000-\$ 249,999$ & & \\
\hline$\$ 250,000-\$ 499,999$ & & \\
\hline$\$ 500,000-\$ 749,999$ & & \\
\hline$\$ 750,000-\$ 999,999$ & & \\
\hline$\$ 1,000,000$ or more & & \\
\hline
\end{tabular}

15. Distribution of Costs.

What percentage of your green power premium was attributable to marketing and administrative costs in 2005?

Are all program costs borne by program participants? Circle one.

If no, please explain

On average, how much did you spend in 2005 to sign up each residential customer (\$/customer)?

$\$$

16. Marketing Strategies. In the table below, please indicate which marketing strategies you used for your green power program in 2005. (check all that apply) Also, please rate the cost-effectiveness of those strategies utilized based on a scale of 1 to 5 , with 5 being the most cost-effective.

\begin{tabular}{|l|l|l|l|l|l|}
\hline & Check (x) & Rating (1-5) & & Check (x) & Rating (1-5) \\
\hline Bill inserts & & & Publicity/feature stories (non-paid) & & \\
\hline Television & & & Events/Presenting to groups & & \\
\hline Telemarketing & & Community challenges & & \\
\hline Direct mail & & Partner with environmental orgs. & & \\
\hline Radio & & Retail partners (co-branding) & & \\
\hline Billboards & & Web-based marketing & & \\
\hline Utility newsletter & & Direct sales to commercial accts. & & \\
\hline Bangtails & & Door-to-door residential & & \\
\hline Newspaper/other print ads & & Kiosks & & \\
\hline Other (please list): & & & \\
\hline
\end{tabular}




\section{Appendix B \\ Table B-1: Utilities Offering Green Pricing Programs in Regulated Markets, 2005}

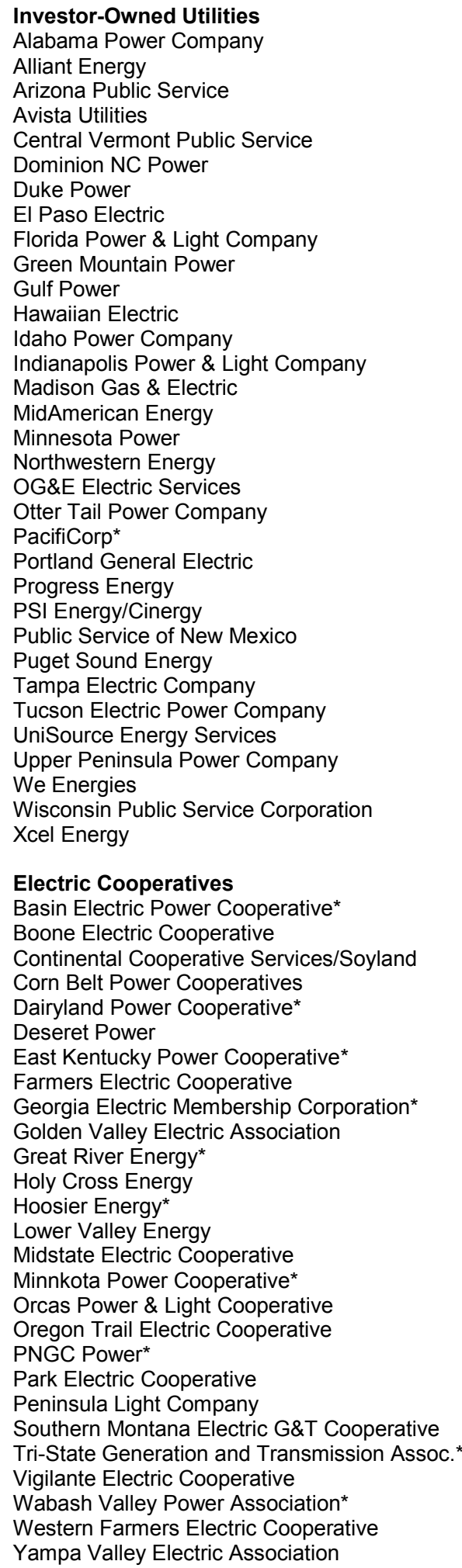

\section{Electric Cooperatives}

Basin Electric Power Cooperative*

Boone Electric Cooperative

Continental Cooperative Services/Soyland

Corn Belt Power Cooperatives

Dairyland Power Cooperative*

Deseret Power

East Kentucky Power Cooperative*

Farmers Electric Cooperative

Georgia Electric Membership Corporation*

Golden Valley Electric Association

Great River Energy*

Holy Cross Energy

Hoosier Energy*

Lower Valley Energy

Midstate Electric Cooperative

Minnkota Power Cooperative

Orcas Power \& Light Cooperative

Oregon Trail Electric Cooperative

PNGC Power*

Park Electric Cooperative

Peninsula Light Company

Southern Montana Electric G\&T Cooperative

Tri-State Generation and Transmission Assoc.

Vigilante Electric Cooperative

Wabash Valley Power Association*

Western Farmers Electric Cooperative

Yampa Valley Electric Association

Federal
Tennessee Valley Authority*

Municipals/Other Public Utilities

City of Alameda

AMP Ohio

Anaheim Public Utilities

City of Ashland

Austin Energy

Benton County PUD

City of Bowling Green

Burbank Water and Power

Cedar Falls Utilities

Chelan County PUD

Clallum County PUD

Clark Public Utilities

Colorado Springs Utilities

Columbia River PUD

Concord Municipal Light Plant

Cowlitz PUD

ElectriCities

Emerald People's Utility District

Eugene Water \& Electric Board

Gainsville Regional Utilities

Grant County PUD

Grays Harbor PUD

lowa Association of Municipal Utilities*

Keys Energy Services

Lansing Board of Water and Light

Lewis County PUD

Lincoln Electric System

Los Alamos Department of Public Utilities

Los Angeles Department of Water and Power

Mason County PUD No. 3

Missouri River Energy Services*

Moorhead Public Service

Muscatine Power and Water

City of Naperville

City of New Smyrna Beach

Oklahoma Municipal Power Authority

Omaha Public Power District

Pacific County PUD \#2

Pasadena Water \& Power

City of Palo Alto Utilities

Platte River Power Authority*

Roseville Electric

Sacramento Municipal Utility District

City of St. Charles

City of St. George Energy Services Department

Salt River Project

City Public Service of San Antonio

Santee Cooper*

Seattle City Light

Silicon Valley Power

Snohomish County PUD

Southern Minnesota Municipal Power Agency*

City Utilities of Springfield

Tacoma Power

City of Tallahassee

Traverse City Light \& Power

Waverly Light \& Power

Wisconsin Public Power Inc. ${ }^{*}$

*denotes program offered through multiple utilities or distribution cooperatives 
Table B-2: Utility/Marketer Green Power Programs in Restructured Electricity Markets, 2005

Consumers Energy

Connecticut Light \& Power

JP\&L

Long Island Power Authority

National Grid (Massachusetts Electric, Nantucket

Electric, Narragansett Electric, Niagara Mohawk)

NYSEG

Rochester Gas and Electric

PECO Energy

PSE\&G

United Illuminating 


\section{Appendix C}

Table C-1: Green Pricing Program Renewable Energy Sales

(as of December 2005)

\begin{tabular}{|c|c|c|c|c|}
\hline Rank & Utility & Resources Used & $\begin{array}{c}\text { Sales } \\
(\mathrm{kWh} / \mathrm{year})\end{array}$ & $\begin{array}{c}\text { Sales } \\
(\mathrm{aMW})^{\mathrm{a}}\end{array}$ \\
\hline 1 & Austin Energy & Wind, landfill gas & $435,140,739$ & 49.7 \\
\hline 2 & Portland General Electric ${ }^{b}$ & $\begin{array}{l}\text { Existing geothermal and } \\
\text { hydro, wind }\end{array}$ & $339,577,170$ & 38.8 \\
\hline 3 & PacifiCorp $^{\text {cd }}$ & Wind, biomass, solar & $234,163,591$ & 26.7 \\
\hline 4 & Florida Power \& Light & Biomass, wind, solar & $224,574,530$ & 25.6 \\
\hline 5 & Sacramento Municipal Utility District ${ }^{\mathrm{e}}$ & $\begin{array}{l}\text { Wind, landfill gas, } \\
\text { small hydro, solar }\end{array}$ & $195,081,504$ & 22.3 \\
\hline 6 & Xcel Energy $^{\text {ef }}$ & Wind & $147,674,000$ & 16.9 \\
\hline 7 & National Grid ${ }^{\text {ghi }}$ & $\begin{array}{l}\text { Biomass, wind, } \\
\text { small hydro, solar }\end{array}$ & $127,872,457$ & 14.6 \\
\hline 8 & Basin Electric Power Cooperative & Wind & $113,957,000$ & 13.0 \\
\hline 9 & Puget Sound Energy & Wind, solar, biogas & $71,341,000$ & 8.1 \\
\hline 10 & OG\&E Electric Services & Wind & $63,591,526$ & 7.3 \\
\hline
\end{tabular}

a An "average megawatt" (aMW) is a measure of continuous capacity equivalent (i.e., operating at a 100\% capacity factor).

${ }^{\mathrm{b}}$ Some products marketed in partnership with Green Mountain Energy Company.

${ }^{\mathrm{c}}$ Includes Pacific Power and Utah Power.

${ }^{\mathrm{d}}$ Some Oregon products marketed in partnership with 3 Phases Energy Services.

${ }^{\mathrm{e}}$ Product is Green-e certified (www.green-e.org). For Xcel Energy, only the Public Service Company of Colorado product is green-e certified.

${ }^{\mathrm{f}}$ Includes Northern States Power, Public Service Company of Colorado, and Southwestern Public Service.

${ }^{\mathrm{g}}$ Includes Niagara Mohawk, Massachusetts Electric, Narragansett Electric, and Nantucket Electric.

h Marketed in partnership with Community Energy, EnviroGen, Green Mountain Energy Company, Mass Energy, People's Power \& Light, and Sterling Planet.

${ }^{\mathrm{i}}$ Some products are certified by Green-e (www.green-e.org) or Environmental Resources Trust http://www.ert.net. 
Table C-2: Total Number of Customer Participants

(as of December 2005)

\begin{tabular}{|c|c|c|c|}
\hline Rank & Utility & Program(s) & Participants \\
\hline 1 & Xcel Energy $^{a}$ & $\begin{array}{l}\text { Windsource } \\
\text { Renewable Energy Trust }\end{array}$ & 49,354 \\
\hline 2 & PacifiCorp ${ }^{\text {cd }}$ & $\begin{array}{l}\text { Blue Sky Block } \\
\text { Blue Sky Usage } \\
\text { Blue Sky Habitat }\end{array}$ & 42,269 \\
\hline 3 & Portland General Electric ${ }^{\mathrm{e}}$ & $\begin{array}{l}\text { Clean Wind } \\
\text { Green Source } \\
\text { Healthy Habitat }\end{array}$ & 40,570 \\
\hline 4 & Sacramento Municipal Utility District & Greenergy $^{\mathrm{b}}$ & 31,229 \\
\hline 5 & Los Angeles Department of Water \& Power & Green Power for a Green LA & 24,380 \\
\hline 6 & Florida Power \& Light ${ }^{\mathrm{f}}$ & Sunshine Energy & 23,066 \\
\hline 7 & $\mathrm{PECO}^{\mathrm{g}}$ & PECO WIND & 22,164 \\
\hline 8 & National Grid ${ }^{\text {hi }}$ & Green $U p^{\mathrm{j}}$ & 20,986 \\
\hline 9 & Puget Sound Energy & Green Power Program & 15,500 \\
\hline 10 & We Energies & Energy for Tomorrow ${ }^{\mathrm{b}}$ & 12,458 \\
\hline 10 & Alliant Energy ${ }^{\mathrm{k}}$ & Second Nature ${ }^{\mathrm{b}}$ & 12,426 \\
\hline
\end{tabular}

${ }^{\mathrm{a}}$ Includes Northern States Power, Public Service Company of Colorado, and Southwestern Public Service.

${ }^{\mathrm{b}}$ Product is Green-e certified (www.green-e.org). For Xcel Energy, only the Public Service Company of Colorado product is Green-e certified. For Alliant Energy, Iowa and Minnesota products are Green-e certified.

${ }^{\mathrm{c}}$ Includes Pacific Power and Utah Power.

${ }^{\mathrm{d}}$ Some Oregon products marketed in partnership with 3 Phases Energy Services.

${ }^{\mathrm{e}}$ Some products marketed in partnership with Green Mountain Energy Company.

${ }^{\mathrm{f}}$ Marketed in partnership with Green Mountain Energy Company.

${ }^{\mathrm{g}}$ Marketed in partnership with Community Energy, Inc.

${ }^{\mathrm{h}}$ Includes Niagara Mohawk, Massachusetts Electric, Narragansett Electric, and Nantucket Electric.

${ }^{i}$ Marketed in partnership with Community Energy, EnviroGen, Green Mountain Energy Company, Mass Energy, People's Power \& Light, and Sterling Planet.

${ }^{\mathrm{j}}$ Some products are certified by Green-e (www.green-e.org) or Environmental Resources Trust http://www.ert.net.

${ }^{\mathrm{k}}$ Includes Interstate Power and Light and Wisconsin Power and Light. 
Table C-3: Customer Participation Rate

(as of December 2005)

\begin{tabular}{|c|c|c|c|c|}
\hline Rank & Utility & $\begin{array}{c}\text { Customer } \\
\text { Participation } \\
\text { Rate } \\
\end{array}$ & $\operatorname{Program}(s)$ & $\begin{array}{c}\text { Program } \\
\text { Start } \\
\text { Year } \\
\end{array}$ \\
\hline 1 & City of Palo Alto Utilities ${ }^{\mathrm{a}}$ & $13.6 \%$ & Palo Alto Green ${ }^{\mathrm{b}}$ & 2003 \\
\hline 2 & Lenox Municipal Utilities $^{c}$ & $12.6 \%$ & Green City Energy & 2003 \\
\hline 3 & Montezuma Municipal Light \& Power $^{\mathrm{c}}$ & $6.3 \%$ & Green City Energy & 2003 \\
\hline 4 & Holy Cross Energy & $6.0 \%$ & $\begin{array}{l}\text { Wind Power Pioneer } \\
\text { Local Renewable Energy Pool }\end{array}$ & $\begin{array}{l}1998 \\
2002\end{array}$ \\
\hline 5 & Sacramento Municipal Utility District & $5.5 \%$ & Greenergy $^{\mathrm{b}}$ & 1997 \\
\hline 6 & Portland General Electric ${ }^{\mathrm{d}}$ & $5.3 \%$ & $\begin{array}{l}\text { Clean Wind } \\
\text { Green Source } \\
\text { Healthy Habitat }\end{array}$ & 2002 \\
\hline 7 & City of Fairbank ${ }^{\mathrm{c}}$ & $4.9 \%$ & Green City Energy & 2003 \\
\hline 8 & Silicon Valley Power ${ }^{\mathrm{a}}$ & $4.8 \%$ & Santa Clara Green Power & 2004 \\
\hline 9 & Moorhead Public Service & $4.7 \%$ & Capture the Wind & 1998 \\
\hline 10 & Central Electric Cooperative ${ }^{\mathrm{e}}$ & $4.6 \%$ & Green Power & 1999 \\
\hline
\end{tabular}

\footnotetext{
${ }^{a}$ Marketed in partnership with 3 Phases Energy Services

${ }^{\mathrm{b}}$ Product is Green-e certified (www.green-e.org).

${ }^{\mathrm{c}}$ Program offered in association with the Iowa Association of Municipal Utilities.

${ }^{\mathrm{d}}$ Some products marketed in partnership with Green Mountain Energy Company.

${ }^{\mathrm{e}}$ Power supplied by PNGC Power.
} 
Table C-4: Price Premium Charged for New, Customer-Driven Renewable Power ${ }^{\mathrm{a}}$ (as of December 2005)

\begin{tabular}{|c|c|c|c|}
\hline Rank & Utility & Resources Used & $\begin{array}{c}\text { Premium } \\
(\boldsymbol{c} / \mathbf{k W h}) \\
\end{array}$ \\
\hline 1 & Xcel Energy ${ }^{\text {bc }}$ & Wind & -0.67 \\
\hline 2 & Edmond Electric $^{\text {bd }}$ & Wind & -0.45 \\
\hline 3 & OG\&E Electric Services ${ }^{\mathrm{b}}$ & Wind & -0.25 \\
\hline 4 & Avista Utilities & Wind & 0.33 \\
\hline 5 & Western Farmers Electric Cooperative & Wind & 0.50 \\
\hline 6 & Austin Energy ${ }^{\mathrm{b}}$ & Wind, landfill gas & 0.70 \\
\hline 6 & Clallam County Public Utility District ${ }^{\mathrm{b}}$ & Landfill gas & 0.70 \\
\hline 8 & PacifiCorp ${ }^{\mathrm{e}}$ & Wind, biomass, solar & 0.78 \\
\hline 9 & Wabash Valley Power Association ${ }^{\mathrm{f}}$ & Landfill gas & 0.90 \\
\hline 10 & Eugene Water and Electric Board ${ }^{\mathrm{b}}$ & Wind & 0.91 \\
\hline
\end{tabular}

${ }^{a}$ Includes only programs that have installed or announced firm plans to install or purchase power from $100 \%$ new renewable resources.

${ }^{\mathrm{b}}$ Premium is variable; customers in these programs are exempt or otherwise protected from changes in utility fuel charges.

${ }^{\mathrm{c}}$ Public Service Company of Colorado only. Product is Green-e certified (www.green-e.org).

d Power supplied by Oklahoma Municipal Power Authority.

${ }^{\mathrm{e}}$ Pacific Power Blue Sky Usage product; only available in Oregon. Product marketed in partnership with 3 Phases Energy Services.

${ }^{\mathrm{f}}$ The premium charged by participating member distribution utilities varies from $0.9 \notin / \mathrm{kWh}$ to $1.0 \notin / \mathrm{kWh}$. 


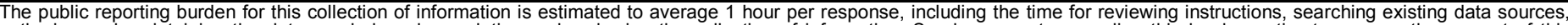

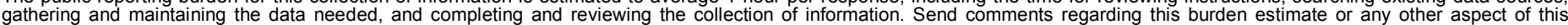

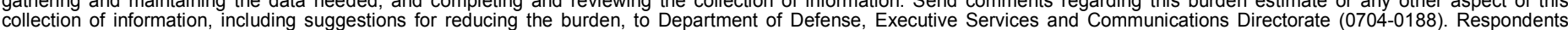

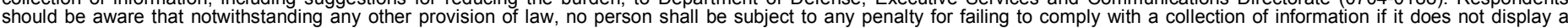

should be aware that notwithstandin

PLEASE DO NOT RETURN YOUR FORM TO THE ABOVE ORGANIZATION.

\begin{tabular}{l|l|l|l} 
1. REPORT DATE $(D D-M M-Y Y Y Y)$ & 2. REPORT TYPE & 3. DATES COVERED (FrOm - TO)
\end{tabular}

October 2006

Technical Report

4. TITLE AND SUBTITLE
Trends in Utility Green Pricing Programs (2005)

5a. CONTRACT NUMBER

DE-AC36-99-G010337

5b. GRANT NUMBER

5c. PROGRAM ELEMENT NUMBER

6. AUTHOR(S)

Lori Bird and Elizabeth Brown

5d. PROJECT NUMBER

NREL/TP-640-40777

5e. TASK NUMBER

ASG6.1003

5f. WORK UNIT NUMBER
7. PERFORMING ORGANIZATION NAME(S) AND ADDRESS(ES)

National Renewable Energy Laboratory

1617 Cole Blvd.

Golden, CO 80401-3393
8. PERFORMING ORGANIZATION REPORT NUMBER

NREL/TP-640-40777

9. SPONSORING/MONITORING AGENCY NAME(S) AND ADDRESS(ES)

10. SPONSOR/MONITOR'S ACRONYM(S) NREL

11. SPONSORING/MONITORING AGENCY REPORT NUMBER

12. DISTRIBUTION AVAILABILITY STATEMENT

National Technical Information Service

U.S. Department of Commerce

5285 Port Royal Road

Springfield, VA 22161

\section{SUPPLEMENTARY NOTES}

\section{ABSTRACT (Maximum 200 Words)}

In the early 1990s, only a handful of utilities offered their customers a choice of purchasing electricity generated from renewable energy sources. Today, more than 600 utilities_or about $20 \%$ of all utilities nationally-provide their customers a "green power" option. Because some utilities offer programs in conjunction with cooperative associations or other publicly owned power entities, the number of distinct programs totals more than 130 . Through these programs, more than 50 million customers have the ability to purchase renewable energy to meet some portion or all of their electricity needs-or make contributions to support the development of renewable energy resources. Typically, customers pay a premium above standard electricity rates for this service. This report presents year-end 2005 data on utility green pricing programs, and examines trends in consumer response and program implementation over time. The data in this report, which were obtained via a questionnaire distributed to utility green pricing program managers, can be used by utilities to benchmark the success of their green power programs.

\section{SUBJECT TERMS}

Green power; green pricing; utilities; electricity customers; renewable energy supplies; renewable energy certificates;

RECs; green power products; customer-acquisition costs; marketing costs; Lori Bird; Elizabeth Brown

\begin{tabular}{|c|c|c|c|c|}
\hline \multicolumn{3}{|c|}{ 16. SECURITY CLASSIFICATION OF: } & \multirow{2}{*}{$\begin{array}{l}\text { 17. LIMITATION } \\
\text { OF ABSTRACT } \\
\text { UL }\end{array}$} & \multirow{2}{*}{$\begin{array}{ll}\text { 18. } & \text { NUMBER } \\
\text { OF PAGES }\end{array}$} \\
\hline $\begin{array}{l}\text { a. REPORT } \\
\text { Unclassified }\end{array}$ & $\begin{array}{l}\text { b. ABSTRACT } \\
\text { Unclassified }\end{array}$ & $\begin{array}{l}\text { c. THIS PAGE } \\
\text { Unclassified }\end{array}$ & & \\
\hline
\end{tabular}

19a. NAME OF RESPONSIBLE PERSON
19b. TELEPHONE NUMBER (Include area code)

